\title{
Petrological Constraints on the Recycling of Mafic Crystal Mushes and Intrusion of Braided Sills in the Torres del Paine Mafic Complex (Patagonia)
}

\author{
J. LEUTHOLD*, O. MÜNTENER, L. P. BAUMGARTNER AND \\ B. PUTLITZ
}

INSTITUTE OF EARTH SGIENCES, GEOPOLIS, UNIVERSITY OF LAUSANNE, LAUSANNE, SWITZERLAND

REGEIVED JULY 23, 2013; ACGEPTED FEBRUARY 28, 2014

Cumulate and crystal mush disruption and reactivation are difficult
to recognize in coarse-grained, shallow plutonic rocks. Mafic min-
erals included in hornblende and zoned plagioclase provide snapshots
of early crystallization and cumulate formation, but are difficult to
interpret in terms of the dynamics of magma ascent and possible
links between silicic and mafic rock emplacement. This study pre-
sents the field relations, the microtextures and the mineral chemistry
of the Miocene mafic sill complex of the Torres del Paine intrusive
complex (Patagonia, Chile) and its subvertical feeder zone. We sum-
marize a number of observations that occur in structurally different,
shallow, plutonic rocks, as follows. (1) The mafic sill complex was
built up by a succession of braided sills of shoshonitic and high-K
calc-alkaline porphyritic hornblende-gabbro and fine-grained mon-
zodiorite sills. Local diapiric structures and felsic magma accumula-
tion between sills indicate limited separation of intercumulus liquid
from the mafic sills. Anhedral hornblende cores, with oliv-
ine + clinopyroxene \pm plagioclase \pm apatite inclusions, crystallized
at temperatures $>900^{\circ} C$ and pressures of $\sim 300$ to $\sim 400$ MPa.
The corresponding rims and monzodiorite matrix crystallized at
$<830^{\circ} C$, $\sim 70$ MPa. This abrupt compositional variation suggests
stability and instability of hornblende during recycling of the mafic
roots of the complex and subsequent decompression. (2) The near
lack of intercumulus crystals in the subvertical feeder zone layered
gabbronorite and pyroxene-hornblende gabbronorite stocks testifies
that melt is more efficiently extracted than in sills, resulting in a cu-
mulate signature in the feeding system. Granitic liquids were ex-
tracted at a higher temperature ( T >950 ${ }^{\circ}$ C) than estimated from
the composition of the granite minimum. We show that hornblende-
plagioclase thermobarometry is a useful monitor for the

*Corresponding author. Present address: School of Earth Sciences, University of Bristol, Wills Memorial Building, Bristol BS8 1RJ, UK. Telephone: +44 (0) 117331 5181. Fax: +44 (0) 117925 3385. E-mail: julien.leuthold@bristol.ac.uk determination of the segregation conditions of granitic magmas from gabbroic crystal mushes, and for monitoring the evolution of shallow crustal magmatic crystallization, decompression and cooling.

KEY WORDS: Patagonian Andes; Chile; crystal mush remobilization; laccolith growth; magma ascent and emplacement; geothermobarometry; Torres del Paine

\section{INTRODUGTION}

It is now well accepted that most laccoliths, plutons and batholiths form by incremental assembly of numerous small intrusions (e.g. Cruden \& McCaffrey, 2002; Coleman et al., 2004; Glazner et al., 2004; Michel et al., 2008; de Saint-Blanquat et al., 2011; Leuthold et al., 2012). These findings are possible based on improvements in analytical precision and accuracy in $\mathrm{U}-\mathrm{Pb}$ isotope dilution thermal ionization mass spectrometry (ID-TIMS) dating of zircons (e.g. Mattinson, 2005; Miller et al., 2007). However, the identification of a single magmatic pulse might be a difficult task (e.g. Horsman et al., 2010). Fieldwork can resolve temporal sequences that are much more closely spaced than the age resolution obtained with zircon dating. Therefore, it plays a key role in identifying single plutonic units. In many cases magmatic textures and internal structures along intra-plutonic contacts are obscured by repetitive emplacement of magma batches, which causes the host material to be remobilized or

(C) The Author 2014. Published by Oxford University Press. All rights reserved. For Permissions, please e-mail: journals.permissions@ oup.com 
rejuvenated after subsequent magma injections (Wiebe, 1993; Paterson et al., 2008; Miller et al., 2011). Shallow plutonic rocks, and in particular sill complexes, offer the possibility to study repetitive emplacement processes as cooling rates are high, which facilitates the identification of single sills (e.g. Sisson et al., 1996). The rapid cooling of single sills of metre to hundred-metre thickness (e.g. Bédard et al., 2007, 2009) facilitates the study of magma emplacement and pluton construction. Sheet-like intrusions and their overall geometries have been investigated using microtextures (e.g. Wiebe \& Collins, 1998; de SaintBlanquat et al., 2006; Horsman et al., 2010), petrological tools (e.g. Bédard et al., 2007, 2009), bulk-rock geochemistry (e.g. Galerne et al., 2008; Leuthold et al., 2013), analogue experiments (e.g. Roman-Berdiel et al., 1995; Kavanagh et al., 2006; Menand, 2008), numerical models (Johnson \& Pollard, 1973; Pollard \& Johnson, 1973; Galerne et al., 2011) and geophysical techniques (Hansen et al., 2004; Thomson \& Hutton, 2004; Polteau et al., 2008). Results show that laccolith assembly occurs with vertical stacking of successive sills, by over-, under- or mid-accretion, or a combination of these. Magma and crystals in suspension are emplaced in melt conduits, with or without subsequent gravity-controlled or dynamically controlled crystal sorting. Antecrysts or xenocrysts (Miller et al., 2007) occur in many volcanic rocks and have also been documented in coarse-grained plutonic rocks (e.g. Blundy \& Shimizu, 1991; Ginibre et al., 2007). Rheological investigations have shown that a rapid viscosity increase is observed at $\sim 40$ 70 vol. $\%$ of crystals, as soon as crystals form an interconnected network, reaching the critical eruptability limit (Marsh, 1981; Vigneresse et al., 1996; Mader et al., 2013). Mafic crystals from an upper solidification front (crystallizing against a cool roof) might be disrupted and transported in a rising, derivative, low-density liquid. Crystal mushes at near-solidus conditions can also be rejuvenated and partially melted by magma replenishment (Murphy et al., 2000; Couch et al., 2001; Wiebe et al., 2004), possibly triggering eruption (Nakagawa et al., 2002; Miller et al., 2011). Such processes result in chemical, mineralogical and textural modifications of magma (Mattioli et al., 2003; Dungan \& Davidson, 2004; Holness et al., 2007; Reuby \& Blundy, 2008; Chiaradia et al., 2009). As magma chemistry and petrography may have been modified through subvolcanic, open-system magmatic processes, such as magma mixing, magma mingling, crystal mush remobilization, assimilation or metasomatism, detailed multidisciplinary studies are necessary to reconstruct the complex evolution of magmatic systems. Plagioclase has been shown to be an important phase to monitor these processes. It often displays complex textures such as normal, reverse, oscillatory or patchy zoning, associated with crystal chemistry variations (e.g. Blundy \& Shimizu, 1991; Kuritani, 1998; Wallace \& Bergantz, 2002; Berlo et al., 2007; Ginibre et al.,
2007; Streck, 2008; Hoshide \& Obata, 2010). Owing to slow element diffusion (Costa et al., 2003), plagioclase may preserve a chronological record of the physico-chemical variations in the magmatic system. Successive distinct crystal populations in volcanic and plutonic rocks have been demonstrated using major and trace element concentrations (e.g. Blundy \& Shimizu, 1991; Ginibre et al., 2007) or in situ Sr isotopic compositions (Davidson et al., 2001), where only the rims are close to equilibrium with their host magmas. Other mineral phases, such as clinopyroxene or hornblende, can be used in a similar manner, if diffusive re-equilibration is sufficiently slow.

The Torres del Paine intrusive complex (TPIC) is a bimodal shallow crustal sill complex located in the Patagonian Andes, connected in its western part to a stock-like feeding system. Jackson \& Pollard (1988) introduced this term to describe ascending magma bodies that may be largely discordant, perhaps by stoping, zone melting, and/or diapiric rise. The western feeding system shows spectacular microtextures within and between single stocks, related to magma ascent. The TPIC is built up of a succession of granitic sills (Michel et al., 2008) underplated by a mafic sill complex (Leuthold et al., 2012, 2013). The latter is composed of an assemblage of 5-50 $\mathrm{m}$ thick hornblende-gabbro and monzodiorite sills, with preserved intra-plutonic contacts between subsequent magma batches. Hereafter, we use the term 'sill' to describe the horizontally emplaced magma, either into solid rock or crystal mush. Field investigations show that channelized magma migration structures are preserved, but only rare modal or grain-size layering is observed, distinguishing the Torres del Paine laccolith from replenished layered intrusions (e.g. Holness \& Winpenny, 2009). Glacier-polished outcrops permit a $3 \mathrm{D}$ view of the Torres del Paine massif, which is thus particularly suitable to study the incremental construction of a laccolith. We describe in detail these field geometries and microstructures, which show that plagioclase and hornblende preserve chemical and textural evidence for recycling of the plutonic roots of the complex. We argue that these minerals are recycled from mid-crustal magma storage reservoirs, along with their olivine and clinopyroxene inclusions, by the host magma. We estimate the physico-chemical conditions of magma emplacement and of the plutonic roots. Rare earth element (REE) data for the major minerals are used to distinguish between recycled components and the products of in situ crystallization. We present a petrogenetic model that explains the principal features of the Torres del Paine mafic complex, which has implications for the construction of shallow crustal laccoliths in general.

\section{TORRES DEL PAINE INTRUSIVE COMPLEX}

The TPIC is an $\sim 80 \mathrm{~km}^{2}$ Miocene composite intrusion exposed in the Patagonian Andes of Southern Chile (Fig. 1). 


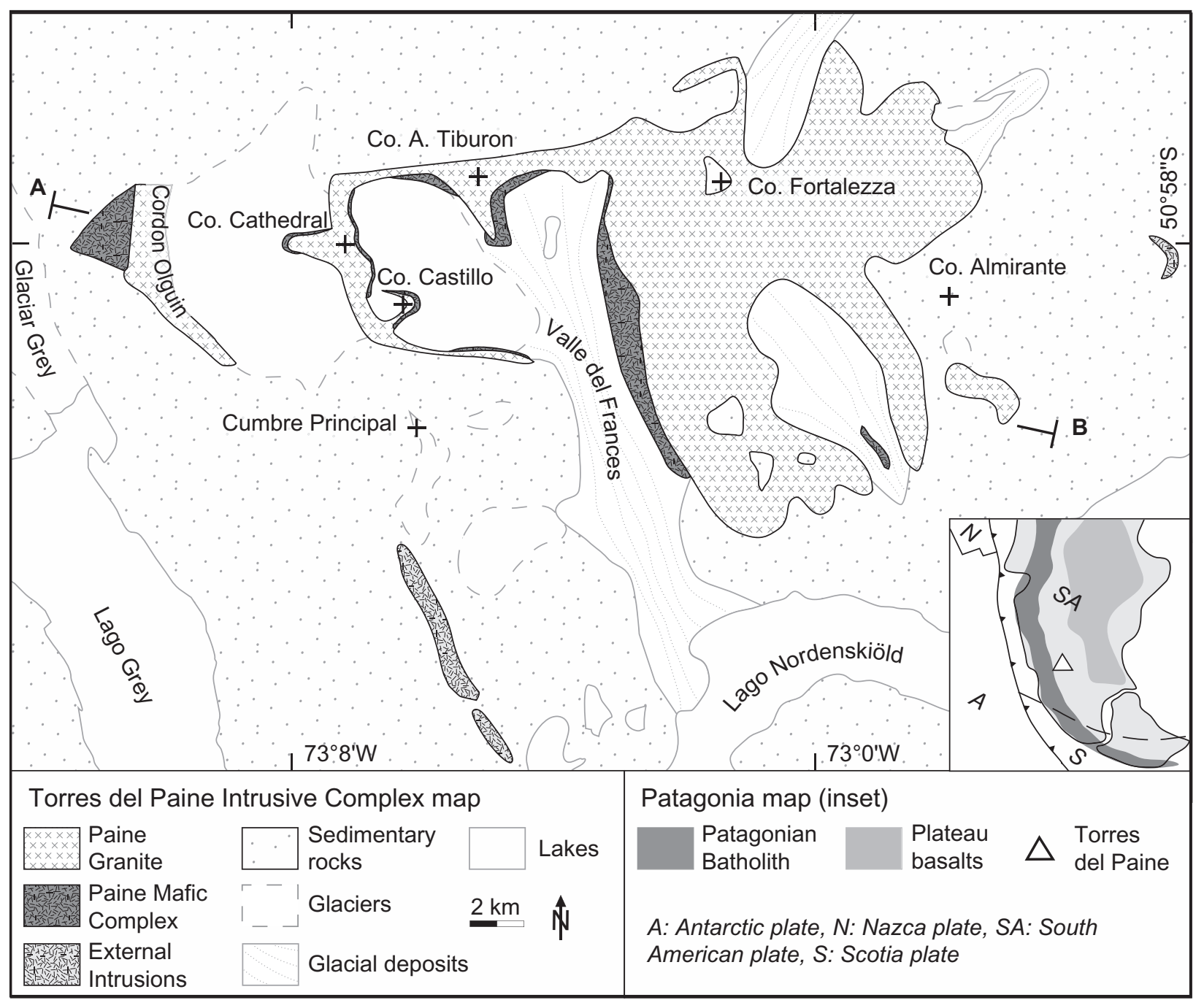

Fig. 1. Simplified geological map of the bimodal Torres del Paine intrusive complex (TPIC), showing the Paine mafic complex and the Paine granite. A-B, line of section shown in Fig. 2. Modified after Michel et al. (2008). The inset map shows the TPIC (triangle) in the regional context.

It was emplaced into early to mid-Cretaceous flysch formations (Cerro Torre and Punta Barossa formations; Wilson, 1983), composed of pelite, marl, conglomerate and quartzite. The TPIC is a bimodal igneous body, built up from multiple pulses of mafic and silicic magma. In its eastern part it is a sill complex, with subhorizontal contacts between distinct sills. The mafic part of the sill complex is formed of hornblende-gabbro and monzodiorite sills, underplating major granitic units. The TPIC western part exhibits subvertical structures that are discordant to the folded country-rocks. This part is referred to as the feeder zone of the laccolith (Fig. 2) (Baumgartner et al., 2006). An anisotropy of magnetic susceptibility (AMS) study by Michel et al. (2007) revealed that the magmatic fabric has a general WNW-ESE subhorizontal strike in the sill complex. The feeder system is composed of WSW-ENE-striking lens-shaped stocks of layered gabbronorite and pyroxene-hornblende gabbronorite, surrounded by monzodiorite. Magnetic lineations are steep to subvertical, west-dipping (Michel et al., 2007). The mafic rocks of the TPIC feeder zone and sill complex constitute the Paine mafic complex, first defined by Michael (1991). As a consequence of glacial erosion the Torres del Paine laccolith is now spectacularly exposed in three dimensions, with $\sim 1000 \mathrm{~m}$ high vertical granitic cliffs overlying $\sim 250 \mathrm{~m}$ of gabbroic and monzodioritic rocks.

Bulk-rock geochemical data indicate that the different mafic units of the TPIC follow high-K calc-alkaline to shoshonitic differentiation trends characterized by variable alkali and $\mathrm{H}_{2} \mathrm{O}$ contents (Michael, 1991; Leuthold et al., 2013). Assimilation-fractional crystallization (AFG) models fail to relate the mafic sill complex cumulates to the overlying granitic units. However, Leuthold et al. (2013) successfully modelled the differentiation of the oldest, topmost granite by $\sim 70 \%$ fractionation from the parental magma 


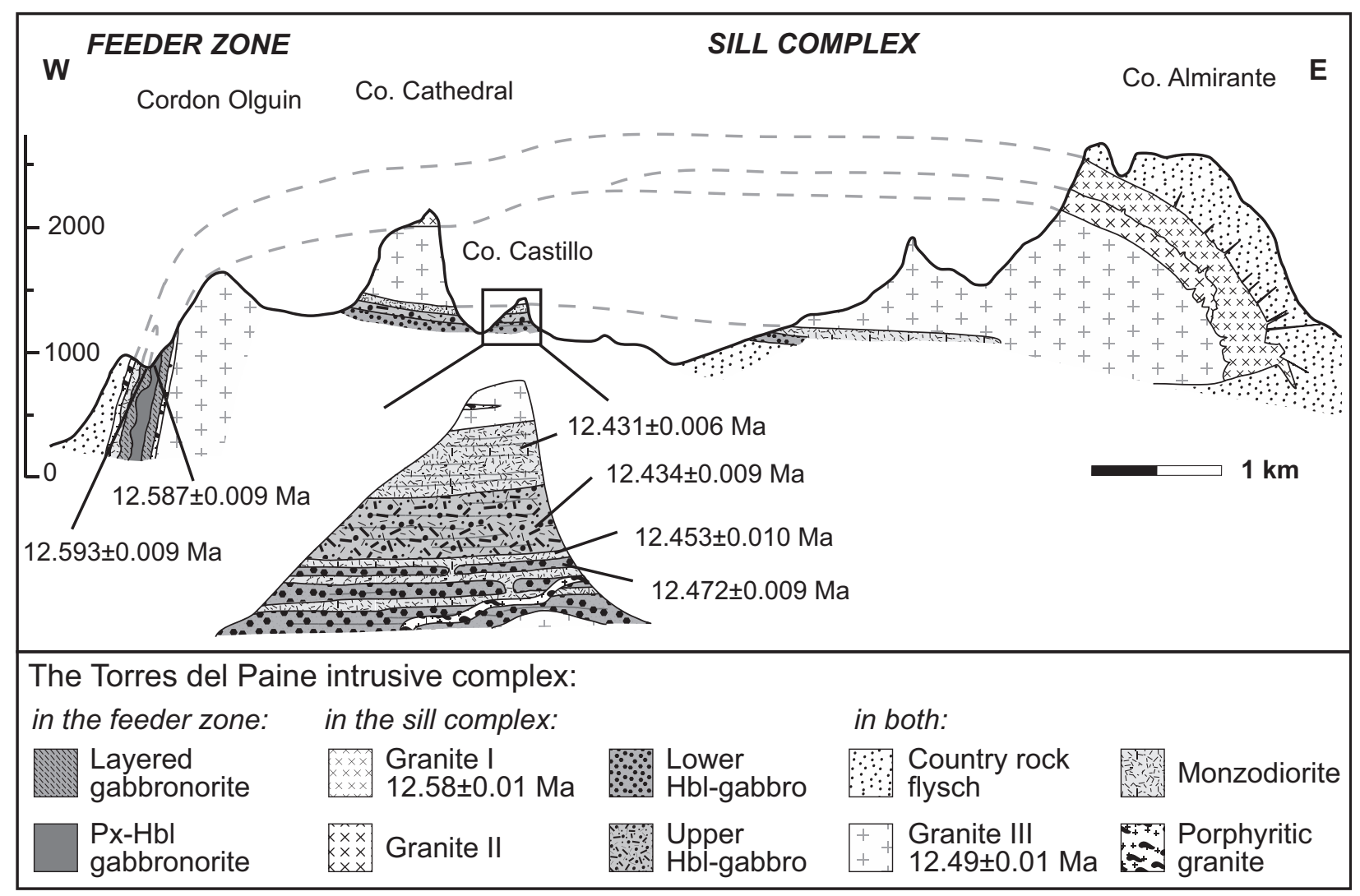

Fig. 2. West-east cross-section across the TPIC laccolith (for the line of section, see Fig. 1). In the western TPIC subvertical intrusions form the feeder zone, and in the eastern TPIC subhorizontal intrusions form the granitic and mafic sill complexes. Modified after Leuthold $e t$ al. (2012). Hbl, hornblende; Px, pyroxene.

of the feeder zone gabbronorite, a high-K basaltic trachyandesite (Michael, 1991). High-precision $\mathrm{U}-\mathrm{Pb}$ zircon IDTIMS dating of the granite has shown that the granitic pulses were assembled between 12.58 \pm 0.01 and $12 \cdot 49 \pm 0 \cdot 01 \mathrm{Ma}$ (Michel et al., 2008; recalculated by Leuthold et al., 2012). Dating of the mafic rocks has revealed that the TPIC was constructed over 160 kyr (Leuthold et al., 2012). The feeder zone layered gabbronorite and pyroxene-hornblende gabbronorite are syn-magmatic, with ID-TIMS zircon $\mathrm{U}-\mathrm{Pb}$ ages of 12.587 \pm 0.009 and $12 \cdot 593 \pm 0.009 \mathrm{Ma}$, identical within error to the age of the oldest granitic unit (Michel et al., 2008). The laccolithic mafic sill complex is younger than the overlying granitic complex, with decreasing ages from the bottom (lower hornblende-gabbro $12 \cdot 472 \pm 0 \cdot 009 \mathrm{Ma})$ to the layered monzodiorite on top (12.431 $\pm 0 \cdot 006 \mathrm{Ma}$; Leuthold et al., 2012).

\section{Geology and petrography of the Feeder Zone}

The TPIC feeder zone, near the eastern end of the Glaciar Grey region, shows subvertical contacts between the intrusive units (Figs 1 and 2). In the mafic rocks, alternating WSW-ENE-trending $10-40 \mathrm{~m}$ thick lenses of olivinebearing pyroxene-hornblende gabbronorite and layered gabbronorite are observed, surrounded by monzodiorite (Leuthold et al., 2013). They are cut to the east by a biotite granite (unit III granite), with a sharp north-south vertical contact.

\section{Layered gabbronorite}

The layered gabbronorites show alternating, centimetrescale, leucocratic plagioclase-rich layers and mesocratic olivine + orthopyroxene + clinopyroxene + plagioclase-rich layers that can be followed continuously along strike for tens of metres (Fig. 3). Abundant poikilitic orthopyroxene and minor clinopyroxene are clearly interstitial with respect to cumulus plagioclase and anhedral olivine. Clinopyroxene can be found as inclusions in orthopyroxene, or vice versa. It is frequently rimmed by hornblende or poikilitic biotite, also including magnetite and ilmenite. In the leucocratic layers, elongated euhedral to subhedral plagioclase crystals are oriented subparallel to the layering and display no evidence of substantial crystal plastic deformation. They become progressively smaller and more anhedral towards the central part of the plagioclase-rich bands (Fig. 4a). Rare apatite, biotite, K-feldspar and quartz occur as intercumulus crystals. Anhedral, reversely zoned plagioclase cores are occasionally included in euhedral 

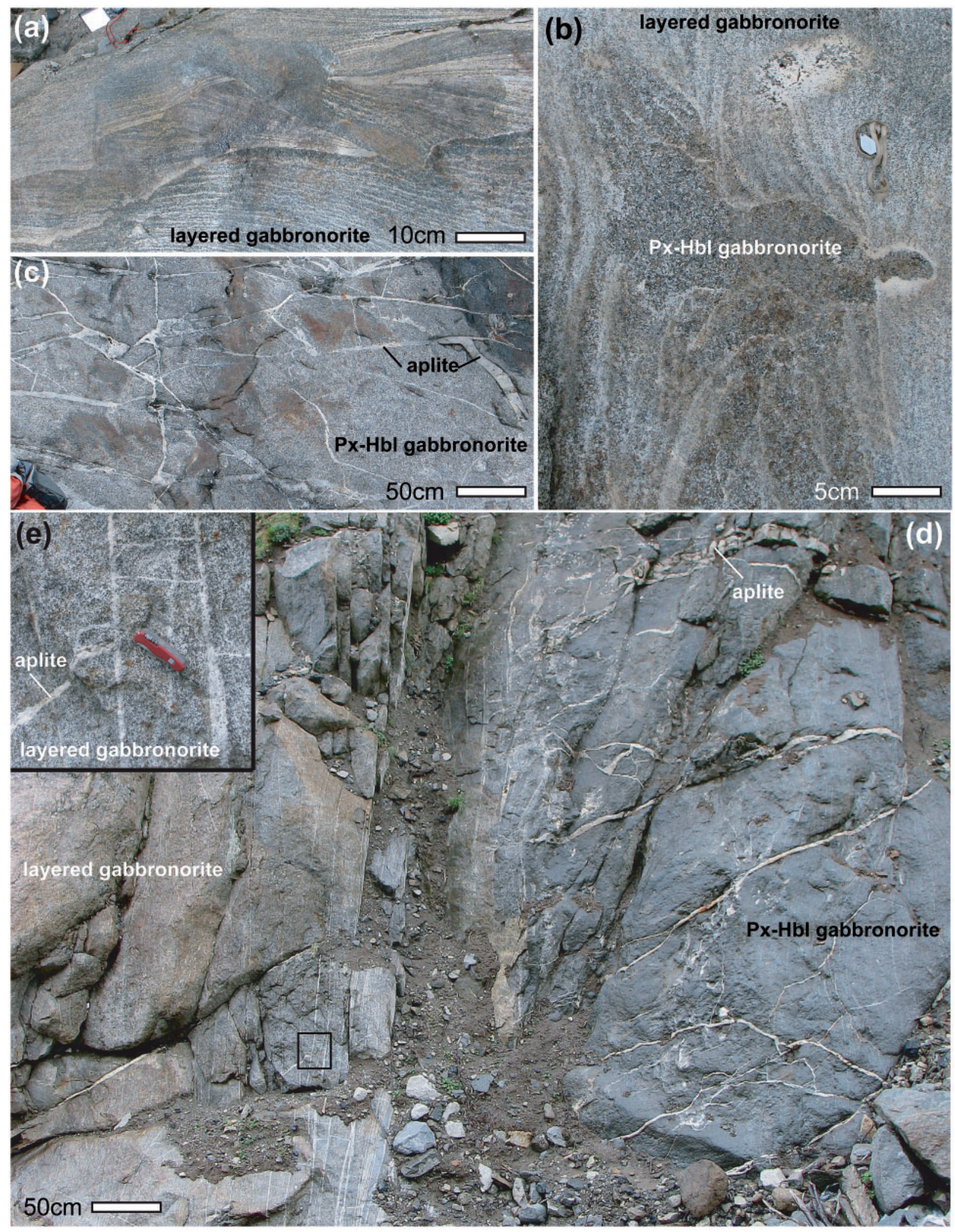

Fig. 3. Field relationships of the mafic rocks in the westernmost feeder zone of the TPIC. (a) Spectacular cross-bedding and sheath fold structures in a layered gabbronorite vertical stock. (b) Ductile deformation of layered gabbronorite by a subsequent pyroxene-hornblende 
plagioclase. The latter commonly displays oscillatory zoning. A summary of the crystallization sequence, determined by mineral microtextures and geochemistry, for all mafic units is illustrated in Fig. 5. Layered gabbronorites contain up to $80 \%$ cumulus crystals; intercumulus phases are more abundant in the plagioclase-rich layers (up to $\sim 50 \%$ ) than in the olivine + pyroxene-rich layers, where intercumulus phases are sometimes as low as 10\% (Fig. 6a). In samples where the magmatic foliation is less developed, hornblende is modally more abundant.

The general strike of the layering in the gabbronorite is subvertical NW-SE. Locally, the layering shows evidence for folding, supersolidus deformation by subsequent magma batches and cross-bedding structures not unlike those seen in sediments (Fig. $3 \mathrm{a}$ and b).

Metasedimentary xenoliths oriented parallel to the layering are occasionally found, but represent less than 2 vol. $\%$ of the layered gabbronorite (locally up to 15-25 vol. \%). These xenoliths form disaggregated lenses of predominantly quartzitic, metapelitic or marly compositions and display features of partial melting. All these observations suggest that the layered gabbronorite was intensely deformed under super-solidus conditions.

\section{Pyroxene-hornblende gabbronorite}

The second mafic rock type in the feeder zone is an olivinebearing pyroxene-hornblende gabbronorite. Based on pegmatite zircon U-Pb ID-TIMS dating, Leuthold et al. (2012) demonstrated that the two units were syn-magmatic. Contacts with layered gabbronorite may be ductile, with distorted layering, or brittle, as evidenced by the occurrence of gabbronorite xenoliths (fig. 3c of Leuthold et al., 2013). In this study, we use the terms 'ductile' and 'brittle' deformation to describe the field structures. These terms may be linked to the ability of the material to flow or to break, respectively (Dingwell, 2006). The pyroxenehornblende gabbronorite is locally cut by a stockwork of aplitic dikes (Fig. 3c and d). Figure 3d shows the complex east-west-trending vertical contact between layered gabbronorite and pyroxene-hornblende gabbronorite.

Poikilitic brown hornblende encloses anhedral olivine, reacted clinopyroxene, orthopyroxene and euhedral plagioclase (Figs $4 \mathrm{~b}$ and 6b). The average modal composition is $50 \%$ plagioclase, $30 \%$ hornblende, $10 \%$ orthopyroxene $+5 \%$ clinopyroxene with traces of olivine + biotite + apatite $+\mathrm{Fe}^{-\mathrm{Ti}}$ oxides, but the proportions of pyroxene and hornblende may vary from one sample to another, with a complete range from layered gabbronorite to pyroxene-hornblende gabbronorite. Inversely zoned, corroded plagioclase cores are occasionally found (Fig. 6b). The overgrown more anorthite-rich plagioclase has the same composition as the plagioclase included in poikilitic hornblende. The intercumulus phases represent less than $30 \mathrm{vol} . \%$ of the rocks and comprise biotite, apatite, plagioclase ( $\sim$ An 50$)$ and green hornblende. The crystallization sequence is identical to that of the layered gabbronorite, with noticeable, more abundant, hornblende crystallization (Fig. 5).

\section{Monzodiorite}

Monzodiorites are typically found at the outer borders of the gabbronorites, but occasionally occur within the gabbronorite units. They are generally fine-grained and contain equigranular plagioclase, biotite and green hornblende in various amounts, with apatite, titanite, magnetite, ilmenite and rare quartz and alkali-feldspar as accessory phases (Figs 4e and 6d). Microtextures suggest that the minerals are in equilibrium.

\section{Unit III granite}

The homogeneous, medium-grained, grey-weathering biotite-hornblende granite (unit III granite, or Co. Cathedral Granite) (Baumgartner et al., 2007; Michel et al., 2008) occurs in the eastern part of the feeder zone and constitutes the Cordon Olguin crest (see Fig. 1). Field relations indicate that this granite postdates the gabbronorite and monzodiorite. This granite is very homogeneous, with only small variations in texture and modal mineralogy.

\section{Porphyritic granite}

Most of the feeder zone gabbronorites and monzodiorites are separated from the country-rock sediments and granitic rocks by a band of porphyritic granite, up to $20 \mathrm{~m}$ thick. These porphyritic granites are composed of phenocrysts of K-feldspar with associated coarse-grained plagioclase, quartz, K-feldspar and biotite. They locally contain abundant quenched centimetre- to decimetre-thick mafic enclaves, which can reach up to $20-50$ vol. $\%$.

\footnotetext{
Fig. 3. Continued

gabbronorite gravity current. (c) A dense leucocratic aplitic fracture network in pyroxene-hornblende gabbronorite. (d) East-west vertical contact between layered gabbronorite and pyroxene-hornblende gabbronorite. Towards the contact with the pyroxene-hornblende gabbronorite stock, the proportion of vertical plagioclase-rich shear bands progressively increases and their orientation rotates from north-south to NWSE. Aplitic veins, with miarolitic cavities, generally dip towards the contact and some show continuity with the plagioclase-rich bands. Thin, sinuous, subvertical plagioclase-rich layers occur within the pyroxene-hornblende gabbronorite. The pyroxene-hornblende gabbronorite was deformed in a brittle way during emplacement of the layered gabbronorite stock and sheared along the contact. Opened veins were filled by aplitic magma. (e) Intersection of leucocratic layered gabbronorite with co-magmatic aplitic veins.
} 


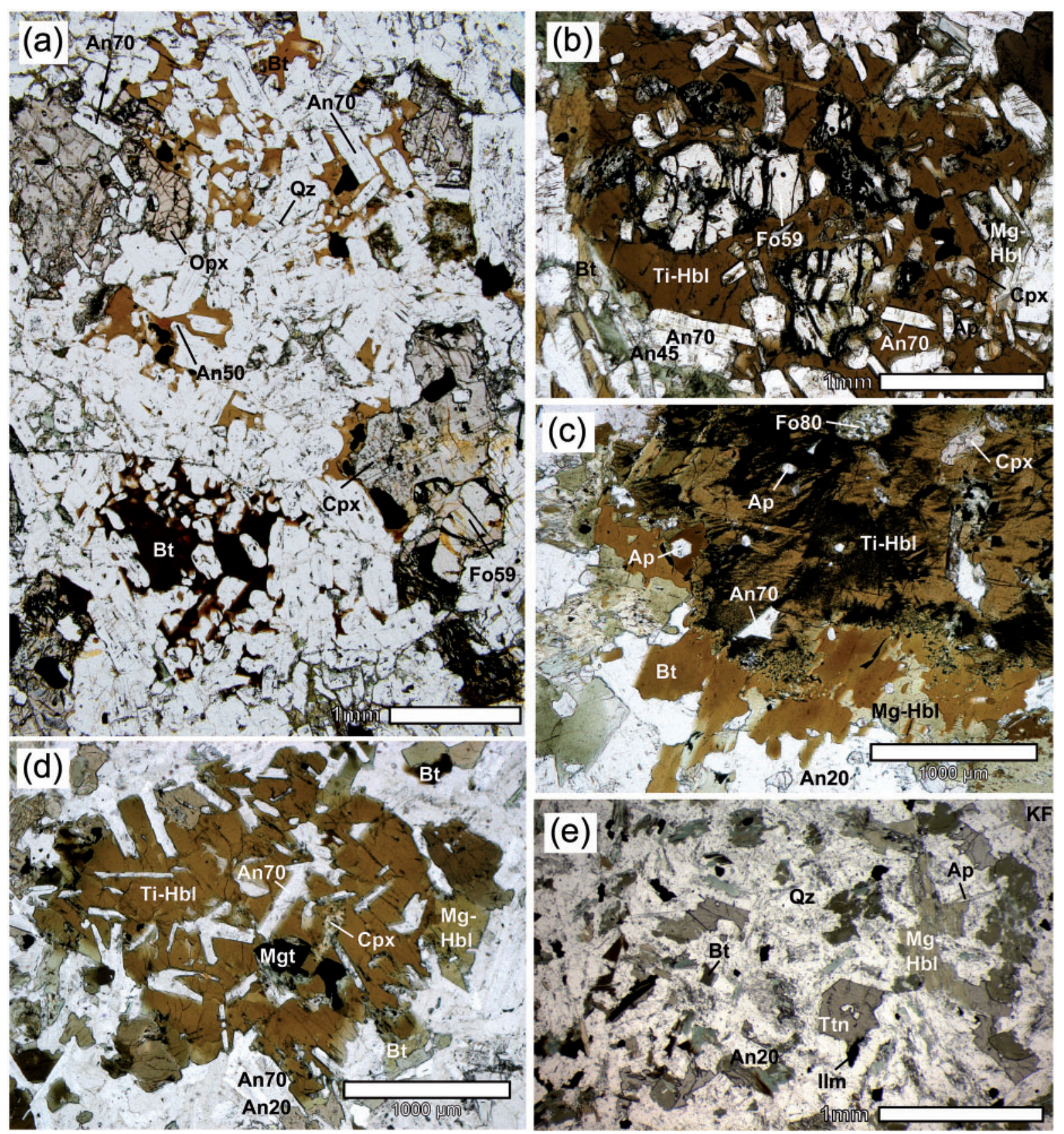

Fig. 4. Thin-section photomicrographs of Paine mafic rocks. Fox, forsterite content; Opx, orthopyroxene; Cpx, clinopyroxene; Anx, An content; Hbl, hornblende; Bt, biotite; Mgt, magnetite; Ilm; ilmenite; Ap, apatite; Ttn, titanite; KF, K-feldspar; Qz, quartz. (a) Feeder zone layered gabbronorite displays alternating melanocratic (olivine + plagioclase + clinopyroxene + orthopyroxene-rich \pm hornblende, visible in the left and right sides of the field of view) and leucocratic (plagioclase-rich \pm biotite \pm hornblende \pm ilmenite) millimetre- to centimetre-thick layers. Matrix crystals are rare and occur in the leucocratic bands. In the leucocratic bands, plagioclase laths are preferentially oriented parallel to the lavers. (b) Most feeder zone pyroxene-hornblende gabbronorites are olivine-bearing. Poikilitic brown pargasite cores enclose anhedral olivine and clinopyroxene, and euhedral plagioclase and apatite inclusions. Biotite, plagioclase, green hornblende and oxides form the interstitial matrix. (c) Lower hornblende-gabbro anhedral brown hornblende macrocrysts show oxide micro-exsolution. Olivine and clinopyroxene anhedral inclusions are found in the most mafic samples. Plagioclase inclusions are rare and occur only in the most differentiated samples. Hornblende cores are rimmed by biotite and subsequent green hornblende rims. Fine-grained matrix is composed of plagioclase + biotite + green hornblende + magnetite + apatite \pm ilmenite \pm orthopyroxene \pm titanite, with \pm quartz and \pm K-feldspar in the most evolved samples. (d) Upper hornblende-gabbro displays poikilitic brown hornblende macrocrysts. Euhedral plagioclase inclusions are abundant, and anhedral olivine and clinopyroxene occur in the most mafic samples. Hornblende is normally zoned over a few tens of micrometres, towards green hornblende. The fine-grained matrix is identical to that in the lower hornblende-gabbro. (e) Monzodiorite from the feeder zone and the mafic sill complex have a similar mineralogy to the lower and upper hornblende-gabbro matrix, with equigranular plagioclase + green hornblende + biotite, in textural equilibrium with titanite + apatite + ilmenite \pm quartz \pm K-feldspar. The hornblende and biotite modal abundance vary strongly. More evolved samples have acicular biotite and hornblende, and porphyritic K-feldspar and quartz occur in the most differentiated ones. 


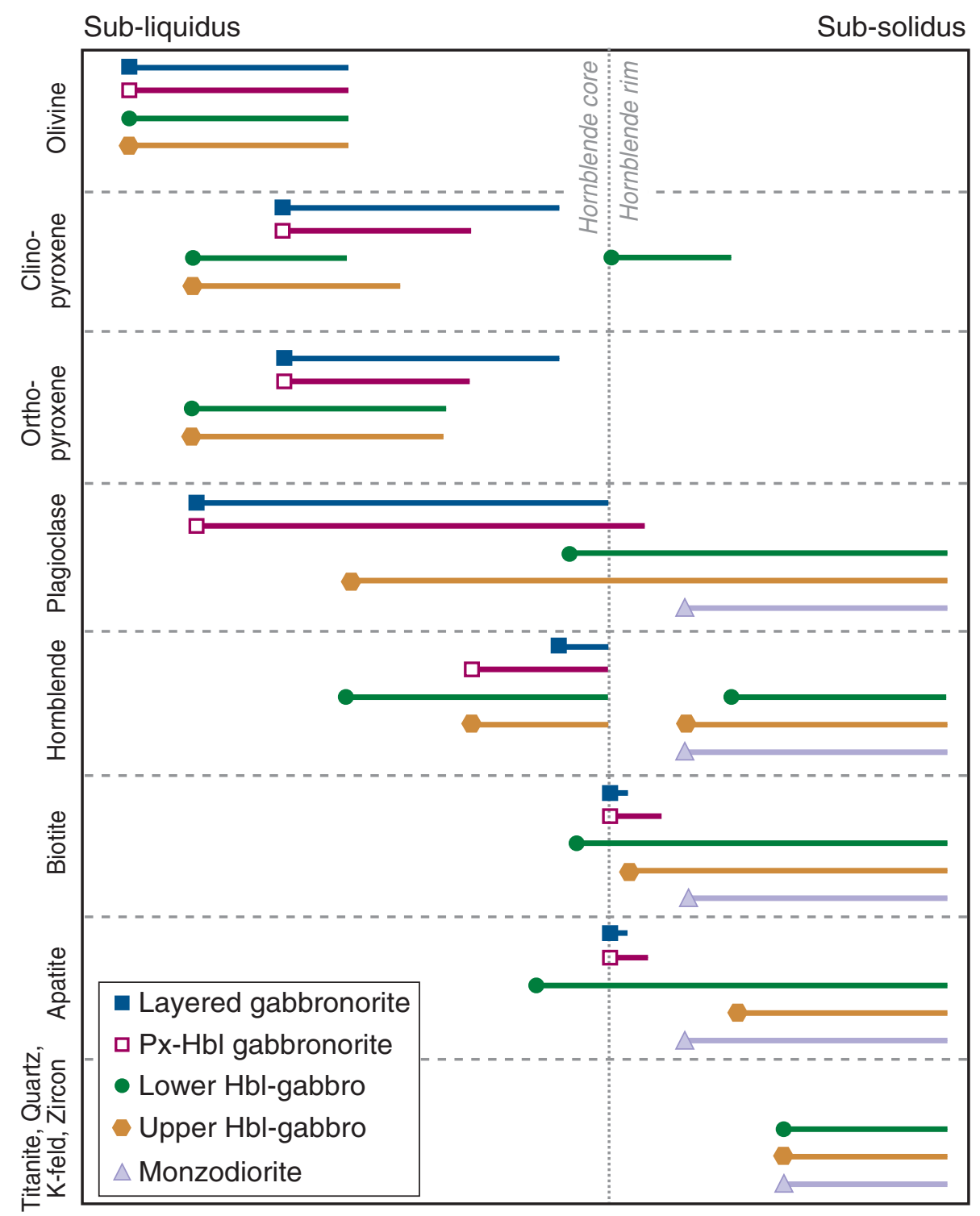

Fig. 5. Crystallization sequence established on the basis of mineral microtextures and chemistry.

\section{Geology and petrography of the sill complex}

Most of the eastern part of the TPIC is a sill complex built up of a succession of gabbroic, monzodioritic and granitic sills, with subhorizontal contacts. Three principal mafic units can be distinguished: (1) lower hornblende-gabbro at the base; (2) upper hornblende-gabbro; (3) layered monzodiorite ranging to monzodioritic enclaves in porphyritic granite towards the contact with the overlying TPIC granite (Figs $7 \mathrm{a}$ and 8). In addition, there are numerous monzodiorite and porphyritic granite sills that are found within the hornblende-gabbro sills. We distinguished single sills based on their modal mineralogy and crystalsize variation. The number of sills varies throughout the mafic sill complex (single sills are numbered in Fig. 8). However, the lower contact with the surrounding rocks is covered by glacial deposits, possibly hiding more sills.

\section{Lower hornblende-gabbro}

Anhedral olivine and clinopyroxene occur only as inclusions in brown hornblende, frequently with apatite (Fig. 4c). Plagioclase inclusions in hornblende cores are rare. Hornblende cores (up to $25 \mathrm{vol}$. \% of the rock) are anhedral, with ilmenite exsolution and resorption embayments. They are rimmed or partially replaced by biotite, which is surrounded by green hornblende (Figs 4c and 6c). Traces of clinopyroxene may be found in hornblende rims and orthopyroxene is frequently rimmed by green 

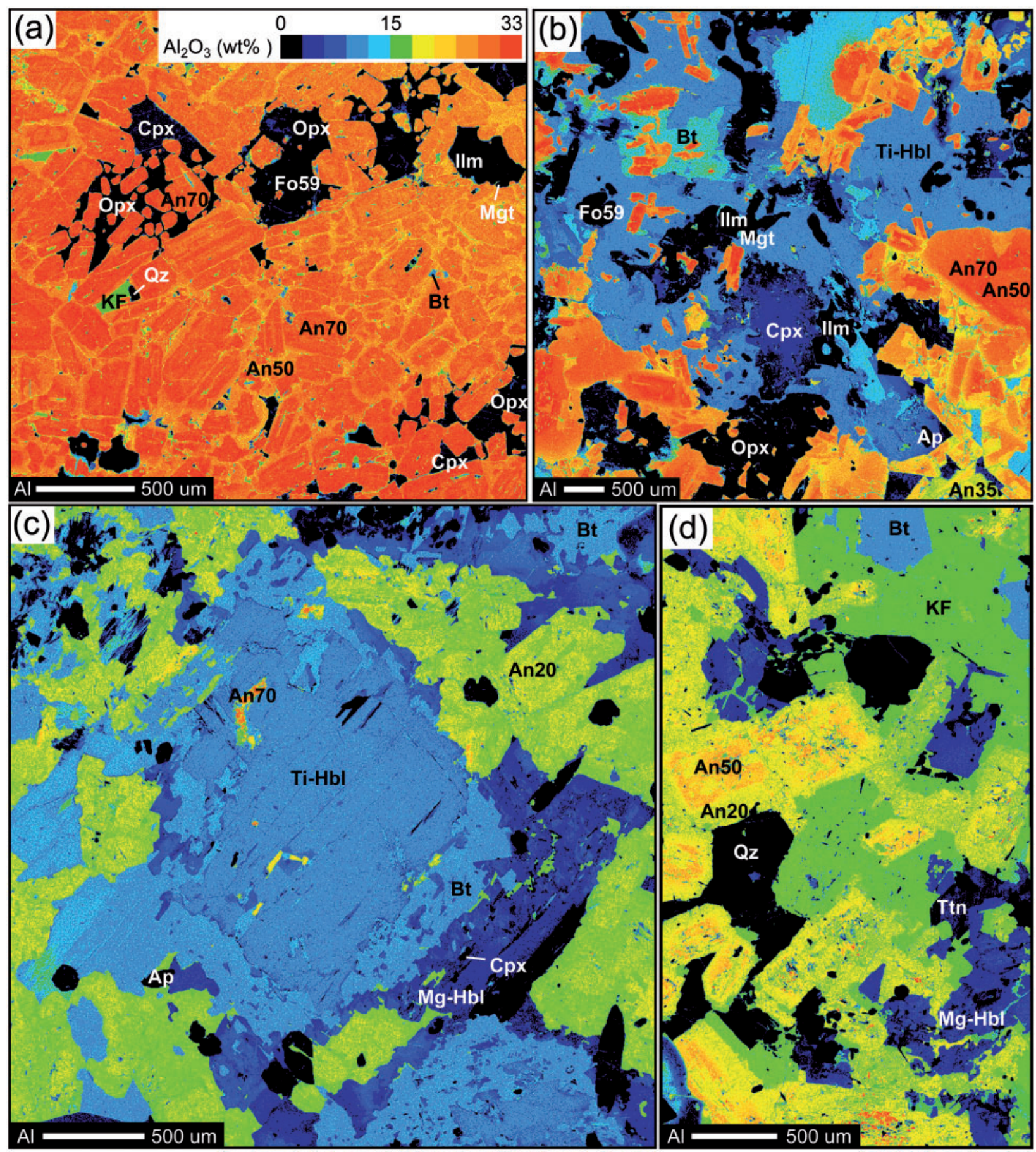

Fig. 6. WDS Al maps for the different mafic units. (a) Feeder zone layered gabbronorite displays adcumulate textures in the plagioclase-rich bands, which have rather uniform compositions. It should be noted that the plagioclase laths show a preferred orientation. More albite-rich plagioclase rims and interstitial plagioclase are rare. Plagioclase inclusions in pyroxene are homogeneous. (b) Olivine and clinopyroxene reacting to hornblende in the feeder zone pyroxene-hornblende gabbronorite. Plagioclase shows anhedral cores mantled by normally zoned more Al-rich plagioclase. (c) Anhedral Al-rich hornblende in lower hornblende-gabbro, rimmed by biotite and Al-poor Mg-hornblende. Al-rich plagioclase inclusions in the hornblende cores are found towards the rim only in the most differentiated samples. The matrix is composed of Al-poor plagioclase, Al-poor hornblende, biotite, apatite and minor titanite, quartz and K-feldspar. (d) The mineralogy of the monzodiorite is similar to that of the interstitial matrix of the hornblende-gabbros. All minerals are in textural equilibrium. A few Al-rich plagioclase cores (An60) are observed. Mineral abbreviations as in Fig. 4. 


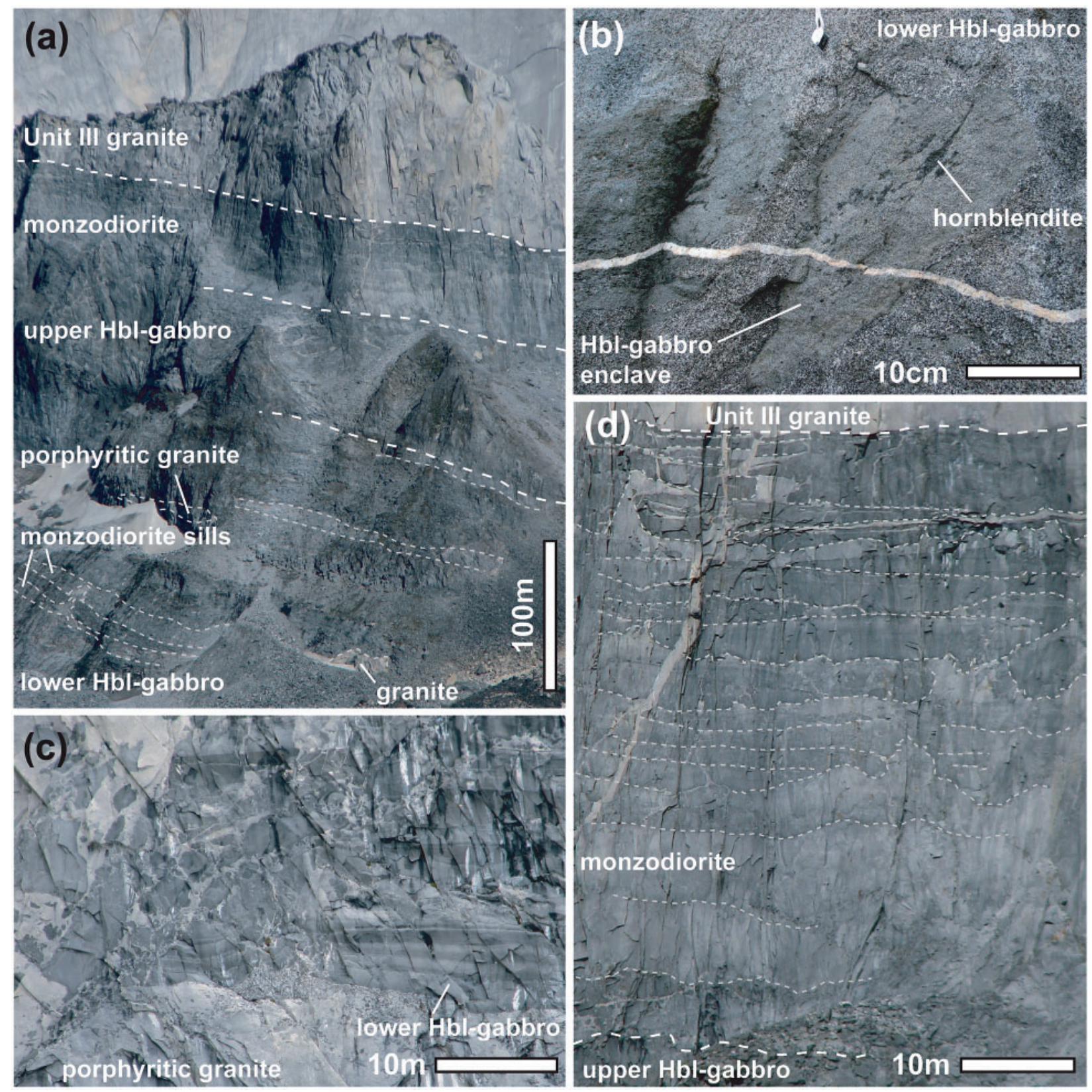

Fig. 7. Field relationships of mafic rocks in the mafic sill complex. (a) Photograph of the Co. Castillo (see Fig. 1 for location) (Leuthold et al., 2013). Contact between mafic sill complex and the TPIC granite is subhorizontal, sharp and straight, with very few mafic enclaves at the base of the granite. The mafic sill complex is composed of lower hornblende-gabbro, upper hornblende-gabbro and a summit accumulation of monzodioritic sills (separated by dashed lines) (see \#1 and \#2 monzodiorite in the text), at the contact with the Unit III granite (or Cathedral Granite). Lower hornblende-gabbro and upper hornblende-gabbro are locally intruded by late monzodioritic sills (see \#4 monzodiorite in the text). Main hornblende-gabbro units are built up of a succession of $10-50 \mathrm{~m}$ thick subunits (outlined with fine white dashed lines). (b) Elongated hornblendite formed by magmatic shearing in a fine-grained gabbroic enclave hosted by lower hornblende-gabbro, boudinaged by subsequent ductile deformation. (c) Detail of the southern zone of Co. Castillo (not visible in Fig. 4a), with layering outlined by modal variations of crystals. Late-stage porphyritic granite partially disrupted the mafic sill complex layered structure. (d) The summit monzodioritic unit: the lower part is characterized by layered monzodiorite (see \#1 monzodiorite in the text); it should be noted that the lower contact is often wavy as a consequence of interstitial felsic liquid accumulating and diapirically rising into the overlying layer. The top part is bimodal, with elongated monzodioritic enclaves (see \#2 monzodiorite in the text) in a porphyritic granite. (Note also the discordant granitoid dike crosscutting the monzodiorite sills.) 


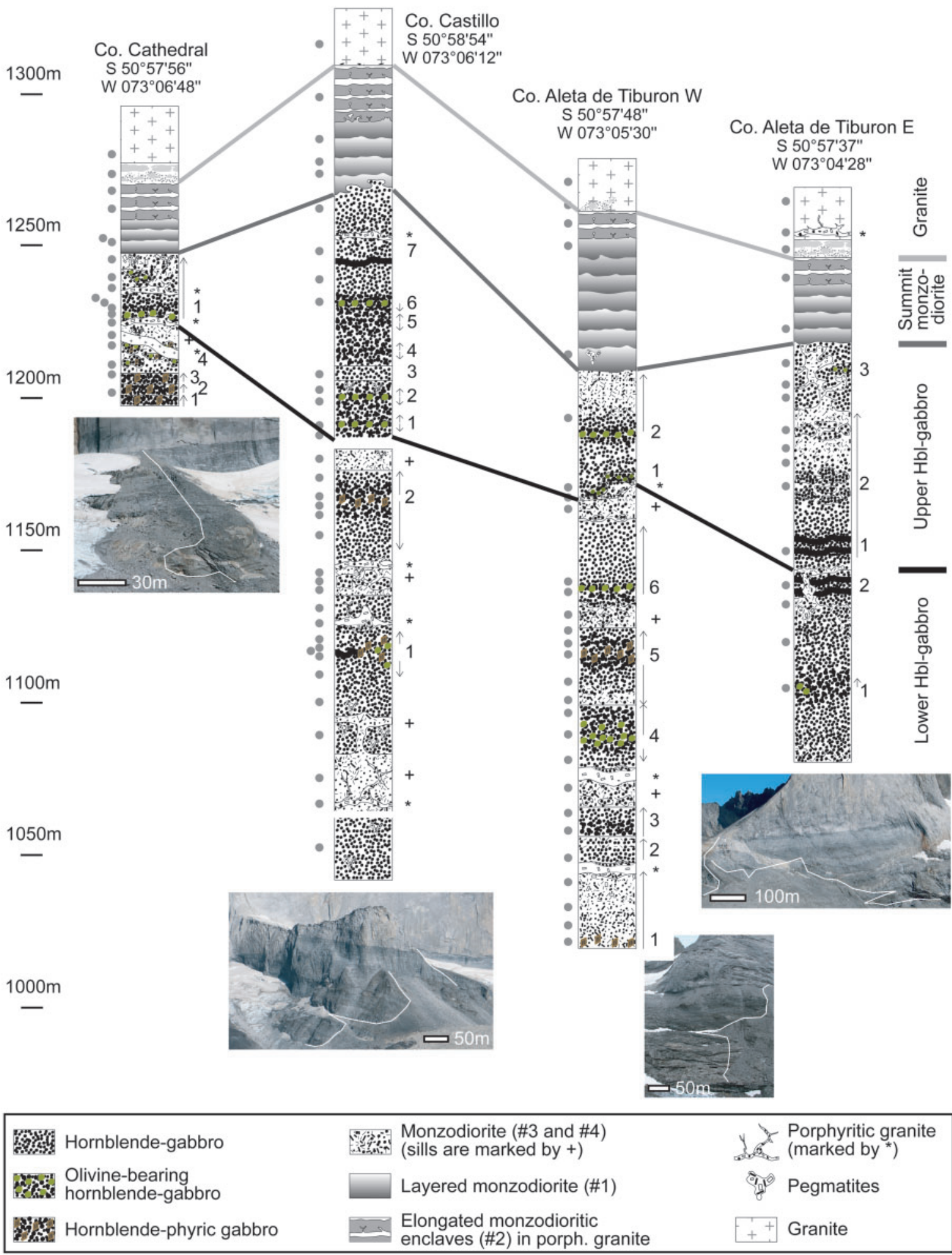

Fig. 8. Correlation between detailed stratigraphic logs through the mafic sill complex (see Fig. 1 for location). The rock types are from bottom to top: (1) lower hornblende-gabbro; (2) upper hornblende-gabbro; (3) monzodiorite; (4) overlying Paine granitic complex. Monzodiorite occurs within hornblende-gabbro units, with progressive modal and mineralogical variations, or as sills. Sills are distinguished by field observations (see text for details): hornblende-gabbro sills are numbered and monzodiorite sills are indicated by a ' + '. Sill thickness and number vary within single units. Sampled profiles are shown with white lines in the photographs. Grey dots on the left of each log show the sample positions. The arrows on the right side show the direction of grading towards more felsic compositions. See also this detailed figure as Electronic Appendix Figure 1. 
hornblende. The intercumulus assemblage is composed of co-crystallized green hornblende, albite-rich plagioclase, biotite, titanite, ilmenite, quartz and rare K-feldspar. Biotite and apatite are more abundant in the lower hornblende-gabbro than in other TPIC hornblende-gabbros. Magnetite is observed in the most mafic samples, and ilmenite and magnetite in the most evolved ones.

The lower hornblende-gabbro is an accumulation of a series of $15-50 \mathrm{~m}$ thick sills, with a total exposed thickness of $30-130 \mathrm{~m}$. Detailed studies of single lower hornblendegabbro sills show symmetrical changes towards their borders in terms of mineralogy, modal proportions and grain size. Centimetre- to metre-thick gradual transitions from olivine-bearing (i.e. as inclusions in brown hornblende) to olivine-free porphyritic hornblende-gabbro, to equigranular hornblende-gabbro, monzodiorite (\#3 monzodiorite, in the next section), monzodiorite with acicular biotite and hornblende, and finally K-feldspar porphyritic granodiorite are locally observed. Gabbro pegmatites are preferentially found along intra-sill borders. Millimetre- to centimetre-sized ultramafic crystal aggregates, rich in (pseudomorphs of) clinopyroxene and hornblende, occur within the lower hornblende-gabbro (Fig. 7b). Locally, layered structures are observed, with a succession of melanocratic rocks grading to mesocratic ones over a distance of $2 \mathrm{~m}$ (Fig. 7c). Such layered structures are only locally found, with an estimated horizontal extent of up to a few hundred metres, but they are generally less than $15 \mathrm{~m}$ thick.

\section{Upper hornblende-gabbro}

The upper hornblende-gabbro is $25-100 \mathrm{~m}$ thick, built up by a succession of $10-50 \mathrm{~m}$ thick sills or tens to hundreds of metres wide lenses (fingers). It is exposed at a stratigraphically higher level than the underlying lower hornblende-gabbro.

Anhedral olivine and clinopyroxene included in hornblende cores are preserved in the most mafic samples. Euhedral plagioclase and poikilitic brown hornblende show ophitic textures (Fig. 4d). Inversely zoned, resorbed plagioclase cores, overgrown by anorthite-rich plagioclase, may be found. Brown hornblende cores and orthopyroxene are overgrown by green hornblende rims. The latter is in textural equilibrium with interstitial minerals such as albite-rich plagioclase, biotite, apatite, titanite, and quartz $+\mathrm{K}$-feldspar in the most evolved samples. The main $\mathrm{Fe}-\mathrm{Ti}$ oxide is ilmenite. Rare magnetite is included in hornblende cores, but is also found in the matrix.

Each sill and lens shows vertical modal variations, with a general tendency for the coarse-grained minerals to be concentrated near the base of single sills, forming olivinebearing, porphyritic hornblende-gabbros. Monzodiorites to gabbro pegmatites occur preferentially at the top of single sills. In Co. Tiburon, monzodioritic magma, expelled from an underlying hornblende-gabbro, has dislocated the overlying hornblende-gabbro into enclaves (Fig. 8).

\section{Monzodiorite}

In general, the textures and mineralogy of the various monzodiorites in the feeder zone and in the mafic sill complex are similar. They are equigranular, fine-grained rocks, showing textural equilibrium between minerals, containing various modal amounts of biotite, green hornblende and plagioclase, with minor apatite, titanite, magnetite, ilmenite, quartz, K-feldspar and rare zircon (Figs 4e and 6d).

Based on field relations, four monzodiorite types can be distinguished in the mafic sill complex: the uppermost monzodiorite shows progressive textural change between a lower layered monzodiorite (\#1) and overlying elongated monzodioritic enclaves hosted in felsic magmas (\#2). Monzodiorite also occurs at the top and sometimes lower borders of hornblende-gabbro sills (as described in the hornblende-gabbro section) (\#3). The hornblendegabbro units are also sometimes intruded by single monzodiorite sills $(\# 4)$.

The lower $30 \mathrm{~m}$ of the layered monzodiorite complex $(\# 1)$ is made of $1-5 \mathrm{~m}$ thick layers (Fig. 7d). Each layer displays modal variations, with increasing proportions of plagioclase, acicular biotite and/or hornblende and rare porphyritic K-feldspar and/or quartz towards the top (becoming mesocratic to leucocratic). Felsic segregations concentrate at the top of each layer and may crosscut the overlying layer. The contact between upper hornblendegabbro and the layered monzodiorite (\#1) shows abundant evidence of mixing and mingling at Co. Castillo.

The upper part of the layered monzodiorite is a succession of fine-grained $\sim 10 \mathrm{~m}$ long and $\sim 1 \mathrm{~m}$ thick monzodioritic enclaves (\#2) embedded in porphyritic granite (Fig. 7d). At the base, decimetre-thick felsic horizons are observed, connected to centimetre to metre long pipes or diapirs rising into the overlying elongated monzodiorite enclaves. The latter represent quenched and contracted horizontal mafic layers with chilled margins. Centimetreto decimetre-thick quenched monzodioritic enclaves are also found within the porphyritic granite. At the contact with the overlying TPIC granite, the felsic horizons and elongated monzodiorite enclaves display sharp contacts and fine-grained, dark rims (Fig. 7d, top part).

Monzodiorites in the lower and upper hornblendegabbro sill borders (\#3) show a complete gradation from (olivine-bearing) hornblende-gabbro and occasionally even differentiation to a granodioritic composition.

The monzodiorite sills (\#4) are intruded by upper and especially lower hornblende-gabbro units and are sometimes vertically interconnected within, or at the border of, previously emplaced hornblende-gabbro sills and always occur at the contact between the lower and upper hornblende-gabbro units. Transitions between monzodiorites 
and hornblende-gabbro sills are generally less than a few tens of centimetres thick, but evidence for mixing and mingling is sometimes well preserved, such as the presence of gabbroic enclaves with cuspate-lobate contacts to the monzodiorite, diapiric ascent of monzodiorite into overlying hornblende-gabbro, and decimetre-wide modal transitions from hornblende-gabbros to monzodiorite.

\section{Units I, II and III granites}

Based on field observations we have distinguished three major granite intrusions (Baumgartner et al., 2007; Michel et al., 2008). These have sharp brittle contacts with each other and cross-cutting intrusive relationships. Granite pulses were under-accreted, based on the brittle contact and cross-cutting relationships. Each pulse appears to have been built up from several (at least 3-5) magma batches, which typically show ductile contacts with each other. The topmost Unit I granite contains biotite and fayalite with rare hornblende. The underlying Unit II medium-grained biotite-hornblende granite contains fayalite and orthopyroxene, with numerous metre-scale mafic enclaves. The lowest granite (Unit III) in the sill complex is a biotite-hornblende granite and is identical to the one exposed in the feeder zone. A $10 \mathrm{~m}$ thick enclave-bearing granite is found at the contact between the mafic sill complex and the overlying granite, at Co. Cathedral. Decametre-thick granitic dikes crosscut the mafic sill complex south of Co. Castillo (partly visible on the left side of Fig. 7c).

\section{Porphyritic granite}

Alkali-feldspar macrocrysts-bearing porphyritic granites crosscut the mafic complex and the granites. They locally contain up to $50 \%$ mafic inclusions, composed of numerous chilled centimetre-thick dioritic enclaves and rarer decimetre-thick fine-grained granodioritic enclaves. Their petrography is identical to that of the felsic granite interlayered with the \#2 monzodiorite at the top of the mafic sill complex. Porphyritic granite forms sills, generally a few tens of centimetres thick. Frequent sharp contacts suggest that these sills intruded into brittle host rock. These sills are interconnected with each other by dikes, and locally form small reservoirs a few tens of metres long and wide, and a few metres thick (see fig. $4 \mathrm{~d}$ of Leuthold et al., 2013). The adjacent mafic rocks show ductile deformation textures, and possibly induced interstitial liquid extraction. Enclaves are distinctly more abundant towards the borders of such small reservoirs, but are also concentrated at the base. Enclave-rich, porphyritic granite pipes or diapirs extend into the overlying hornblende-gabbro units. They occasionally show miarolitic cavities in the centre, indicating saturation of a fluid phase.

Mafic inclusions within the porphyritic granite are of monzodiorite $(5-50 \mathrm{~cm})$ and granodiorite $(\sim 1 \mathrm{~m})$. Most monzodiorite inclusions are circular, but some are cuspate-lobate or elongated. They are generally homogeneous in grain size, but distinctly finer-grained than the porphyritic granite. A distinct feature is the enrichment in biotite and K-feldspar towards the border of the enclaves.

\section{ANALYTIGAL METHODS}

Major element compositions of minerals were determined using a five-spectrometer JEOL JXA-8200 electron microprobe at the Institute of Mineralogy and Geochemistry, University of Lausanne, Switzerland. Operating conditions involved a $10-15 \mathrm{kV}$ accelerating voltage and a beam current of 10-20 nA, depending on the analysed mineral. Natural and synthetic silicates and oxides were used as standards.

In situ mineral trace element contents were analysed by laser ablation inductively coupled plasma mass spectrometry (LA-ICP-MS) using a Perkin-Elmer ELAN 6100DRC ICP-MS system at the Institute of Mineralogy and Geochemistry, University of Lausanne, connected to a $193 \mathrm{~nm}$ excimer laser system $\left(\right.$ Geolas $\left.^{\circledR}\right)$. The laser was operated with a spot size of between 30 and $120 \mu \mathrm{m}$, a frequency of 5-10 Hz and an energy of 90-140 mJ. Electron microprobe data were used as an internal standard for all analysed minerals. We used NIST SRM612 for external standardization of feldspars, olivine, clinopyroxene, orthopyroxene and hornblende, and NIST SRM610 for biotite and apatite. Raw data were reduced off-line using the LAMTRACE software (Jackson, 2008).

\section{MINERAL GHEMISTRY Olivine}

Olivine shows a wide range of compositions in terms of $\mathrm{Mg \#}$ and $\mathrm{Ni}$ content, ranging from Fo79-68 and $1400-500 \mu \mathrm{g} \mathrm{g}^{-1} \mathrm{Ni}$ in the mafic sill complex lower and upper hornblende-gabbros to Fo61-55 and 140-110 $\mu \mathrm{g} \mathrm{g}^{-1}$ $\mathrm{Ni}$ in the feeder zone layered gabbronorite and pyroxenehornblende gabbronorite (Fig. 9; see also Electronic Appendix Table 1; the supplementary material is available for downloading at http://www.petrology.oxfordjournals. org).

\section{Plagioclase}

Based on texture and chemical composition, three types of plagioclase may be distinguished (Figs 10 and 11; see also Electronic Appendix Table 1): (1) An 55 anhedral cores; (2) euhedral An 70 cores; (3) An 20 rims.

(1) Reversely zoned anhedral cores are found in all mafic units of the TPIC, except in the lower hornblende-gabbro. The composition of resorbed, anhedral plagioclase varies from An60 to An49, but single grains are fairly homogeneous $( \pm 3 \% \mathrm{An})$. They show patchy zoning and sieve textures filled by more An-rich plagioclase. 

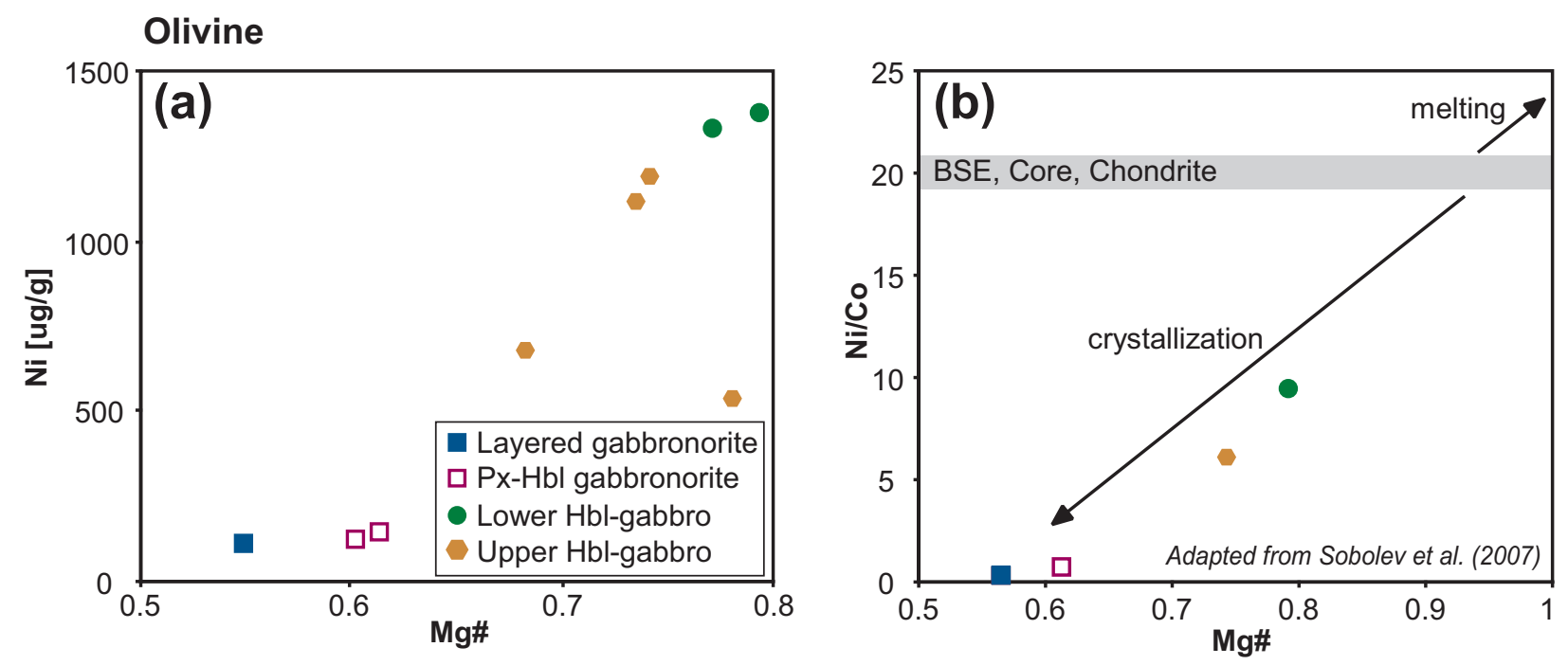

Fig. 9. (a) $\mathrm{Ni}$ vs $\mathrm{Mg} \#$ (electron microprobe analyses) and (b) Ni/Co (LA-ICP-MS analyses) vs Mg\# of average olivine. The Mg-and Ni-poor olivine from the feeder zone gabbronorites are distinctly less primitive than the olivine from the mafic sill complex hornblende-gabbros.
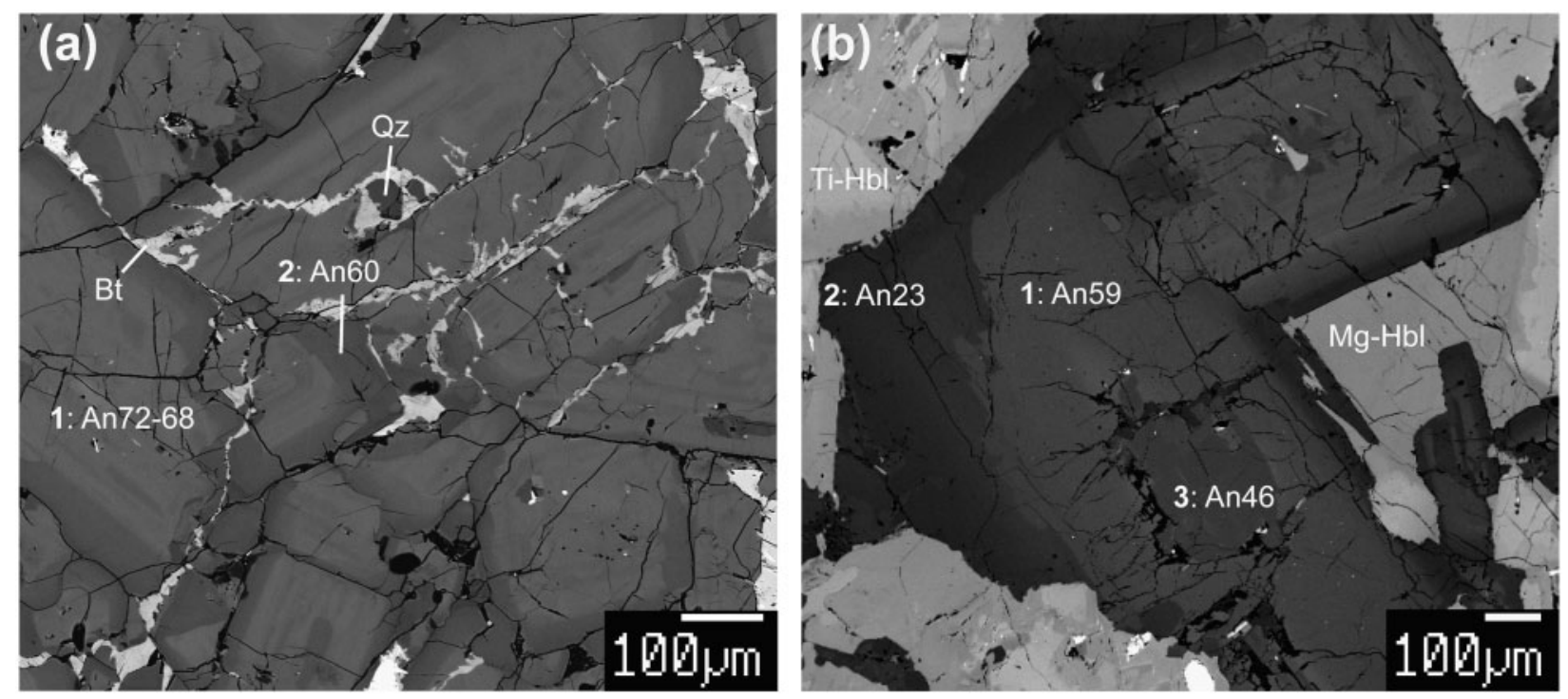

Fig. 10. Plagioclase BSE images, from (a) a feeder zone layered gabbronorite and (b) an upper hornblende-gabbro. Plagioclase displays complex textures, associated with chemical variations. Three types of plagioclase can be distinguished. (1) An-rich crystals are concentrically cracked, partially resorbed and/or reversely zoned. In the feeder zone layered gabbronorite, they display discrete oscillatory zoning. They are rimmed by (2) an An-poor plagioclase with a sharp transition (smaller than $\sim 10 \mu \mathrm{m}$, rarely up to a few tens to hundreds of micrometres). Plagioclase rims display normal zoning. They are distinctly thinner in the feeder zone gabbronorites than in the mafic sill complex hornblende-gabbros or the monzodiorite. (3) Anhedral cores, sometimes with patchy zoning, are rimmed by An-rich plagioclase. They are rare in the upper hornblende-gabbro and monzodiorites of the mafic sill complex, minor in feeder zone gabbronorites (less than $\sim$ lvol. \%) and absent in lower hornblende-gabbro. (a) also shows grain boundaries and fractures filled by late-stage biotite, An-poor plagioclase and quartz.

(2) An-rich plagioclase (An50-80) inclusions are found in all TPIC layered gabbronorites (An74-69, maximum An79), pyroxene-hornblende gabbronorites (An73-56, maximum An81), and upper hornblende-gabbros (An74-51, maximum An77) (Fig. 11). An-rich plagioclase constitutes most of the layered gabbronorite leucocratic layers, but is also found as inclusions in pyroxenes. There are also rare An72-56 (maximum An73) plagioclase grains in the lower hornblende-gabbro and An61-47 in monzodiorite. The chemical variability between plagioclase cores in a single sample is very small, with two notable exceptions. First, in the layered gabbronorite, oscillatory zoning is sometimes 

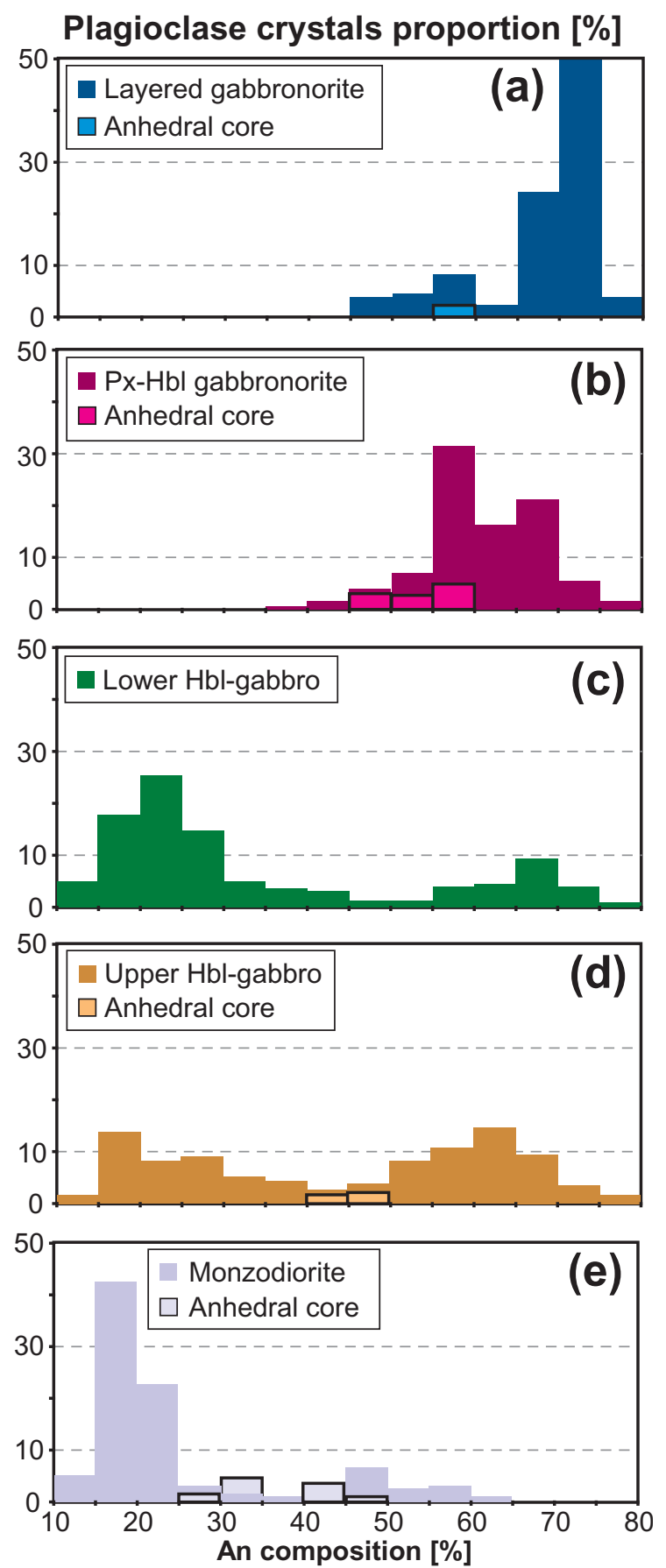

Fig. 11. Histograms of plagioclase composition, based on electron microprobe analysis, BSE images and thin-section observations. Three distinct groups can be distinguished, associated with the crystal textures illustrated in Fig. 10. (1) The plagioclase cores are An80-55 in gabbronorite and hornblende-gabbro units. (2) Plagioclase rims in lower and upper hornblende-gabbros are similar to matrix crystals and to plagioclase in monzodiorite (An35-15). In feeder zone gabbronorites, the most Na-rich plagioclase is An40. (3) Anhedral plagioclase in feeder zone gabbronorites and upper hornblende-gabbro is An60-40, and An50-25 in monzodiorite. observed in the An-rich cores, typically with 5-10\% variation in An content. Second, plagioclase crystals with resorbed and concentrically cracked cores show a general increase in An content towards the idiomorphic borders (Fig. 10).

(3) In the mafic sill complex plagioclase cores display an abrupt transition (usually $<10 \mu \mathrm{m}$ ) to albite-rich rims. The composition of the rims ranges from An27 to An13 in monzodiorite and from An32 to An17 in the lower and upper hornblende-gabbros; these are sometimes normally zoned. In contrast, plagioclase rims in the feeder zone gabbronorites are only a few tens of micrometres thick, are normally zoned, and have An contents $>40 \%$.

Plagioclase REE patterns are generally higher in feeder zone gabbronorites than in the mafic sill complex (Fig. 12). Plagioclase in monzodiorite and hornblende-gabbros from the mafic sill complex displays steeper REE patterns and especially lower heavy REE.

\section{Clinopyroxene}

Clinopyroxene is always found as resorbed inclusions in brown hornblende, except in layered gabbronorite. Clinopyroxene cores are enriched in $\mathrm{Al}$, $\mathrm{Ti}$ and $\mathrm{Mg}$ relative to the rims that are in contact with hornblende (Fig. 6b). In terms of $\mathrm{Al}, \mathrm{Mg} \#$ and $\mathrm{Ti}$, the clinopyroxenes of the upper hornblende-gabbro ( $\mathrm{Mg} \# \sim 82-80)$ and pyroxene-hornblende gabbronorite ( $\mathrm{Mg} \#$ 81-77) (Fig. 13a and b) are similar. Clinopyroxene from lower hornblendegabbro $(\mathrm{Mg} \# \sim 81-75)$ is distinctly enriched in $\mathrm{Ti}$ and $\mathrm{Al}$ relative to all other TPIC mafic rocks, and layered gabbronorite clinopyroxene $(\mathrm{Mg} \# \sim 74-72)$ is $\mathrm{Al}, \mathrm{Mg}, \mathrm{Ti}$ and Na poor.

In terms of trace elements (Fig. 13c and d), Eu and $\mathrm{Sr}$ negative anomalies $\left\{\mathrm{Sr}^{*}=\mathrm{Sr}_{\mathrm{n}} /\left[\left(\operatorname{Pr}_{\mathrm{n}}+\mathrm{Nd}_{\mathrm{n}}\right)\right]\right.$ and $\left.\mathrm{Eu}^{*}=\mathrm{Eu}_{\mathrm{n}} /\left[\left(\mathrm{Sm}_{\mathrm{n}}+\mathrm{Gd}_{\mathrm{n}}\right)\right]\right\}$ are pronounced in clinopyroxene from feeder zone gabbronorites, and subtle to nonexistent in lower and upper hornblende-gabbros. $\mathrm{Cr}$ is highest in lower hornblende-gabbro, and below $500 \mathrm{\mu g} \mathrm{g}^{-1}$ in the layered gabbronorite (Fig. 13d).

\section{Orthopyroxene}

Orthopyroxene is abundant in both gabbronorites, but comparatively minor in the hornblende-gabbros. There is a clear chemical difference between the gabbronorites, with Ti-rich, low-Mg\# (70-65) orthopyroxene, and the hornblende-gabbros, with Ti-poor and high-Mg\# (81-74) orthopyroxene. Similar to clinopyroxene, orthopyroxene REE patterns display weak but significant Eu negative anomalies in gabbronorites, but no anomalies in hornblende-gabbros.

\section{Hornblende}

Two types of hornblende can be distinguished: (1) Ti-rich brown cores (kaersutite, Ti-pargasite); (2) Ti-poor green rims 


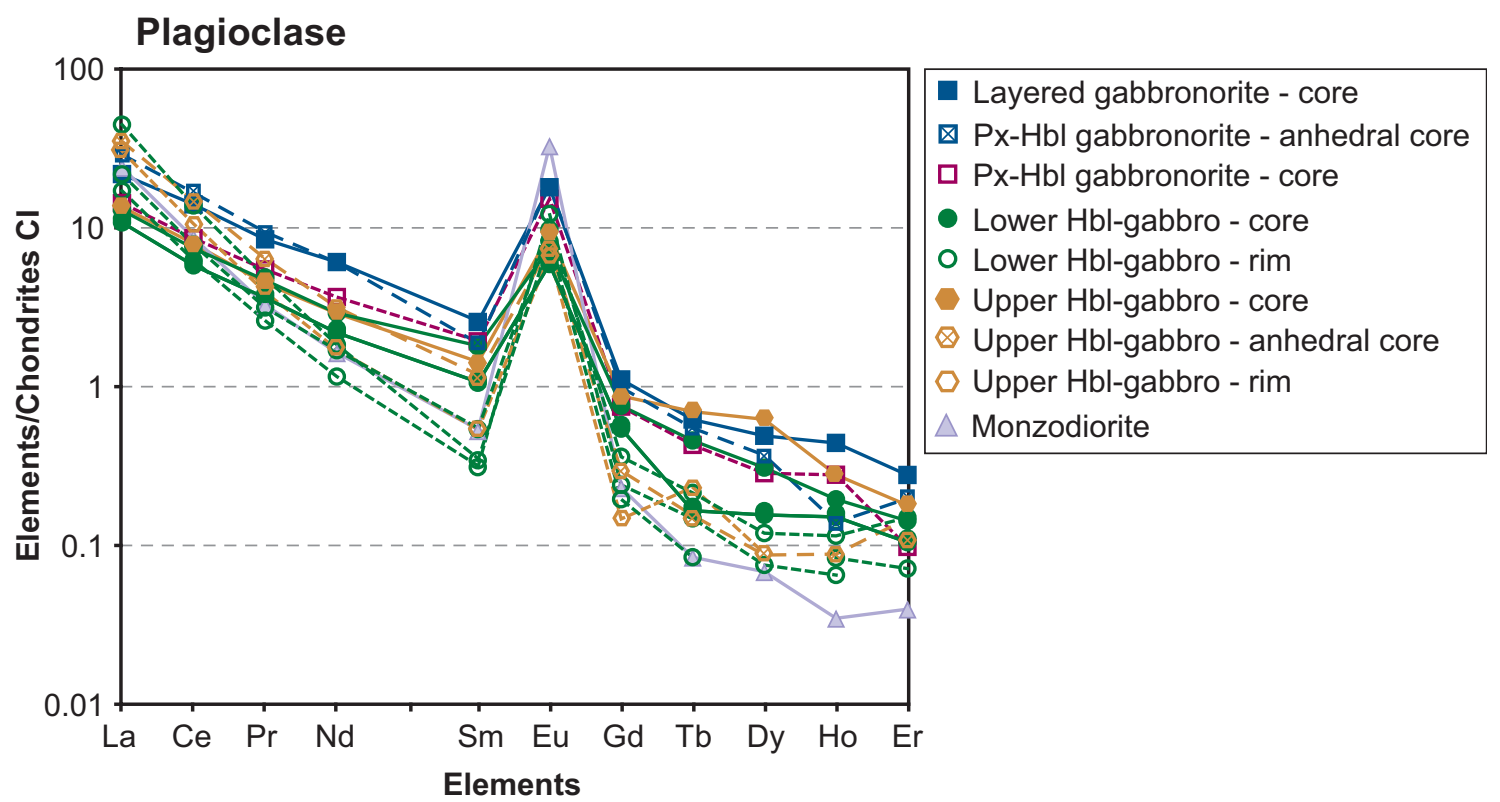

Fig. 12. Average plagioclase core, rim and resorbed core composition, normalized to CI chondrite of Boynton (1984).

and matrix crystals ranging from magnesio-hornblende to actinolitic hornblende.

(1) Hornblende core compositions indicate that the melts in equilibrium have alkaline compositions, based on the classification of Molina et al. (2009). Electron microprobe data demonstrate that feeder zone gabbronorites have similar amphibole compositions, based on their $\mathrm{Al}_{(\mathrm{IV})}$ and $\mathrm{Ti}$ systematics (Fig. 14); however, hornblende is subhedral in pyroxene-hornblende gabbronorite and interstitial or poikilitic in layered gabbronorite. Hornblende from the lower hornblende-gabbro displays the highest alkali, $\mathrm{Al}_{(\mathrm{IV})}, \mathrm{Ti}$ and edenite contents relative to other TPIC hornblendes. The feeder zone gabbronorites and mafic sill complex upper hornblende-gabbro have compositions that cannot be distinguished in terms of major or trace elements.

(2) Hornblende in the lower hornblende-gabbro displays corroded cores and subidiomorphic rims, separated by finegrained biotite. Compositional traverses of hornblende display two distinct plateau compositions, with a narrow transitional zone between core and rim. The rims and matrix amphiboles have similar compositions. Normal zoning is also a characteristic feature of upper hornblendegabbros. Hornblende in monzodiorites is green magnesio- to actinolitic hornblende, with low $\mathrm{Al}_{(\mathrm{IV}}, \mathrm{Ti}$ and $\mathrm{Na}+\mathrm{K}$, similar to the hornblende rims in the lower and upper hornblende-gabbros.

Hornblende trace element data are illustrated in Fig. 14c and d. Similar to clinopyroxene, hornblende from layered gabbronorite and monzodiorite displays negative $\mathrm{Sr}$ and $\mathrm{Eu}$ anomalies, whereas there are weak or no anomalies in lower hornblende-gabbro, and intermediate anomalies in pyroxene-hornblende gabbronorite and upper hornblende-gabbro, respectively. In contrast to major elements, hornblende rims and matrix crystals in lower and upper hornblende-gabbros are clearly different from those in monzodiorites (Fig. 14c): the hornblende rims in the lower and upper hornblende-gabbros are REE-poor compared with the associated cores, whereas the monzodiorite hornblende displays the highest REE content and the lowest $\mathrm{Eu}^{*}$. Hornblende rims in the lower and upper hornblende-gabbros and monzodiorite hornblende are low in $\mathrm{Ba}\left(<10 \mu \mathrm{gg}^{-1}\right)$ relative to all other amphiboles $\left(>200 \mu \mathrm{g} \mathrm{g}^{-1}\right)$.

\section{Biotite}

Biotite is homogeneous within single samples (Electronic Appendix Table 1). It is neither zoned nor resorbed. Biotite in olivine-bearing lower and upper hornblende-gabbros is $\mathrm{Mg}$ - and Si-rich and K- and Ti-poor. Monzodiorite biotite is $\mathrm{Mg}$ - and Si-poor and $\mathrm{K}$ - and Ti-rich, and biotite compositions in olivine-free hornblende-gabbros are intermediate between the two. This compositional variability is also seen in biotite in the gabbronorites, albeit at overall higher $\mathrm{Ti}$ content than for biotite from the hornblendegabbros.

\section{CRYSTALLIZATION SEQUENGE}

On the basis of textural observations and mineral chemical data, it is possible to establish a characteristic crystallization sequence for each unit of the Paine mafic complex (Fig. 5). The two feeder zone gabbronorites have similar 


\section{Clinopyroxene}
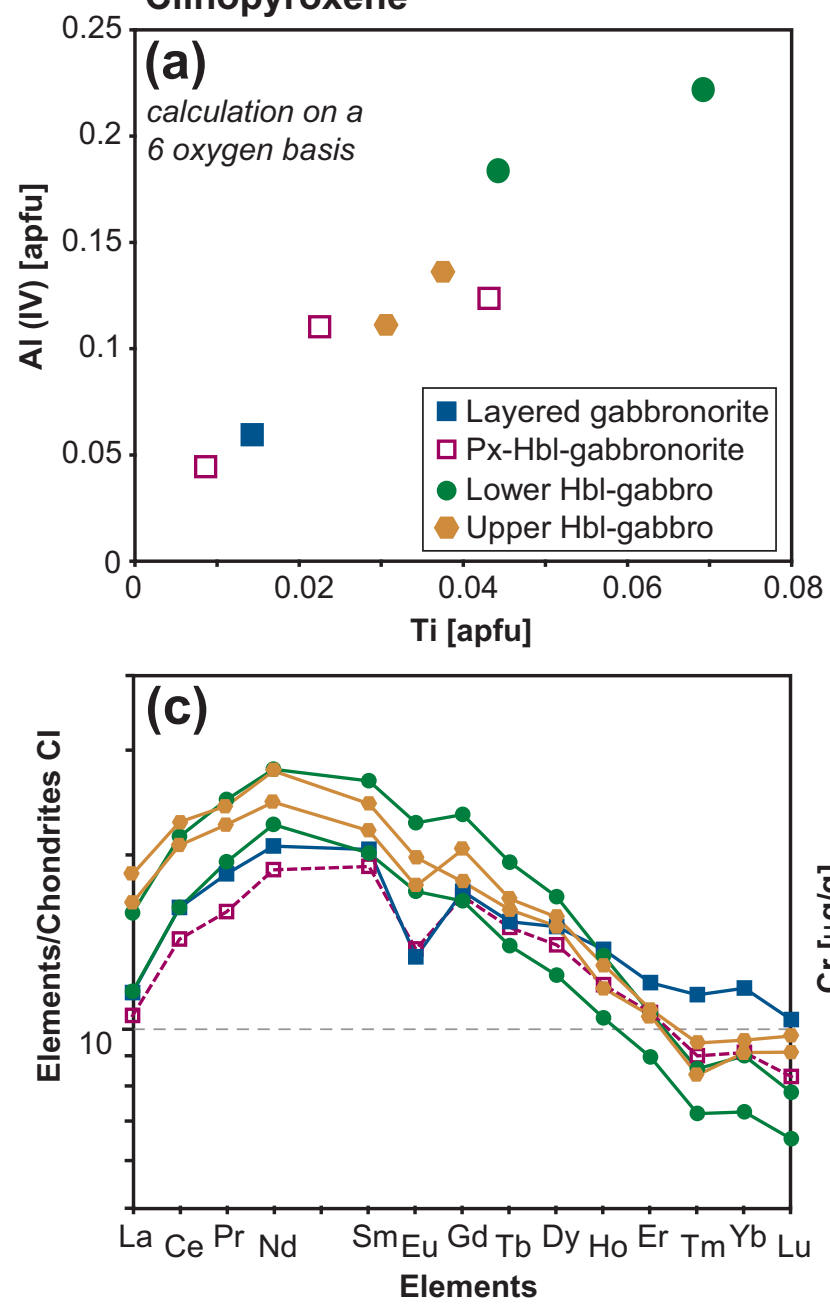
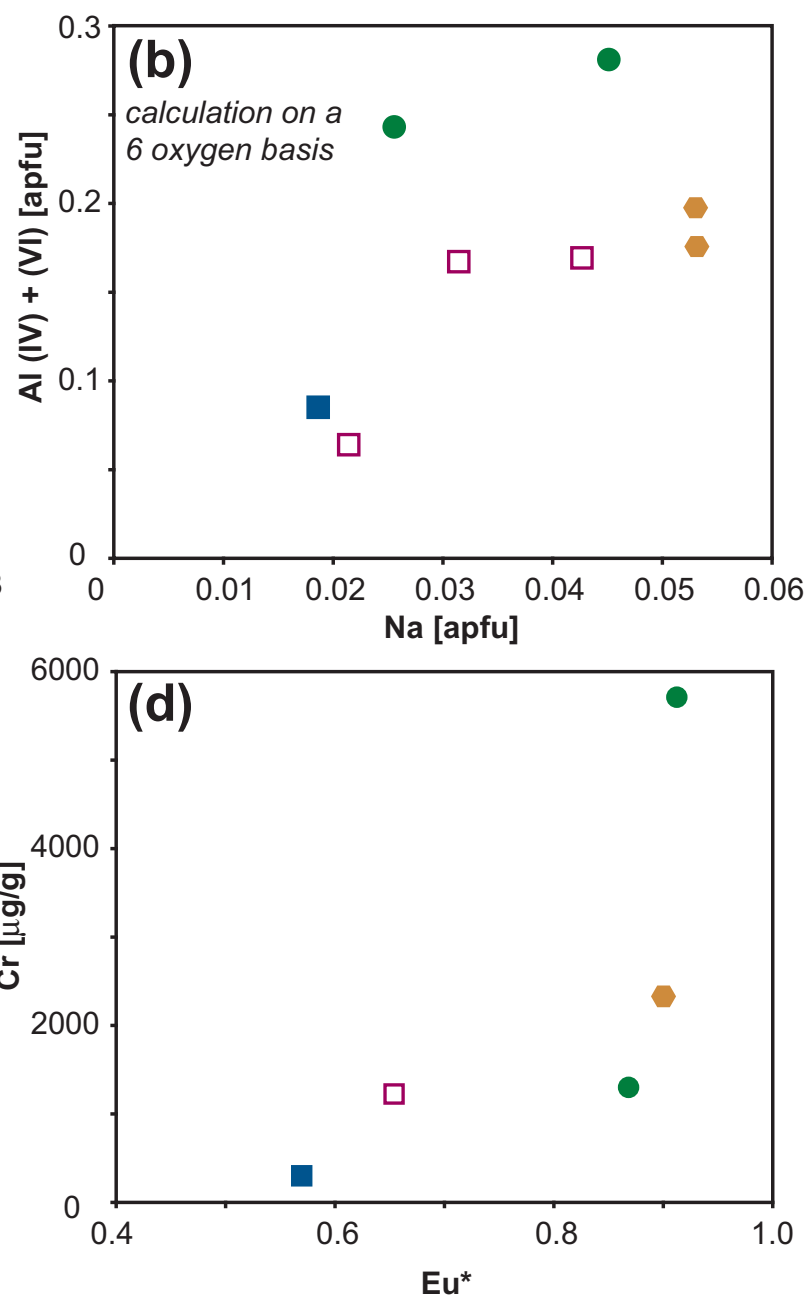

Fig. 13. (a, b, d) Average clinopyroxene compositions. Clinopyroxenes in the feeder zone gabbronorites are Al-, Ti-, Na-, Cr-poor with negligible Eu*. The lower hornblende-gabbro clinopyroxenes are rich in Al, Ti and $\mathrm{Cr}$, and display a weak Eu negative anomaly. (c) Average REE patterns for clinopyroxene of all samples, normalized to CI chondrite of Boynton (1984).

mineral chemistry and crystallization sequence: olivine $\rightarrow$ plagioclase $($ An $\sim 70) \rightarrow$ orthopyroxene, clinopyroxene, Fe- $\mathrm{Ti}$ oxides $\rightarrow$ Ti-hornblende $\rightarrow$ biotite, $\pm \mathrm{K}$-feldspar, \pm quartz. The two units can be distinguished only by textural criteria and the modal proportion of hornblende. Typical late-stage minerals are absent in most samples.

The lower hornblende-gabbro crystallization sequence is olivine $\rightarrow$ clinopyroxene, orthopyroxene $\rightarrow$ Ti-hornblende, apatite, magnetite $\rightarrow$ plagioclase $(\mathrm{An} \sim 70)$, biotite $\rightarrow$ plagioclase (An 25), Mg-hornblende, $\mathrm{Fe}-\mathrm{Ti}$ oxides $\rightarrow \mathrm{K}$ feldspar, quartz, titanite, zircon. It should be noted that, in contrast to the other TPIC gabbroic rocks, in the lower hornblende-gabbro Ti-rich hornblende precedes An70 plagioclase.

The upper hornblende-gabbro crystallization sequence is olivine $\rightarrow$ clinopyroxene, orthopyroxene, $\mathrm{Fe}-\mathrm{Ti}$ oxides $\rightarrow$ plagioclase $(\mathrm{An} \sim 70)$, Ti-hornblende $\rightarrow$ plagioclase
(An 25), Mg-hornblende, biotite, apatite $\rightarrow$ titanite, quartz, K-feldspar. It is very similar to that in the gabbronorites, except for pyroxene saturation prior to plagioclase.

In monzodiorites, biotite, green hornblende, plagioclase (An 20), apatite, titanite, magnetite, ilmenite and also quartz and K-feldspar are co-crystallizing.

\section{GHEMIGAL PROFILES THROUGH THE MAFIC SILL GOMPLEX}

Mineral and bulk-rock analyses of a detailed vertical section $(\sim 250 \mathrm{~m})$ of the Paine mafic complex at Co. Castillo are presented in Fig. 15 and Electronic Appendix Table 2. The lower hornblende-gabbro basal sill complex displays inverse variations of bulk-rock $\mathrm{Zr}$ and $\mathrm{Mg \#}$. Towards the lower and upper borders, bulk-rock incompatible elements increase whereas compatible elements decrease. The 

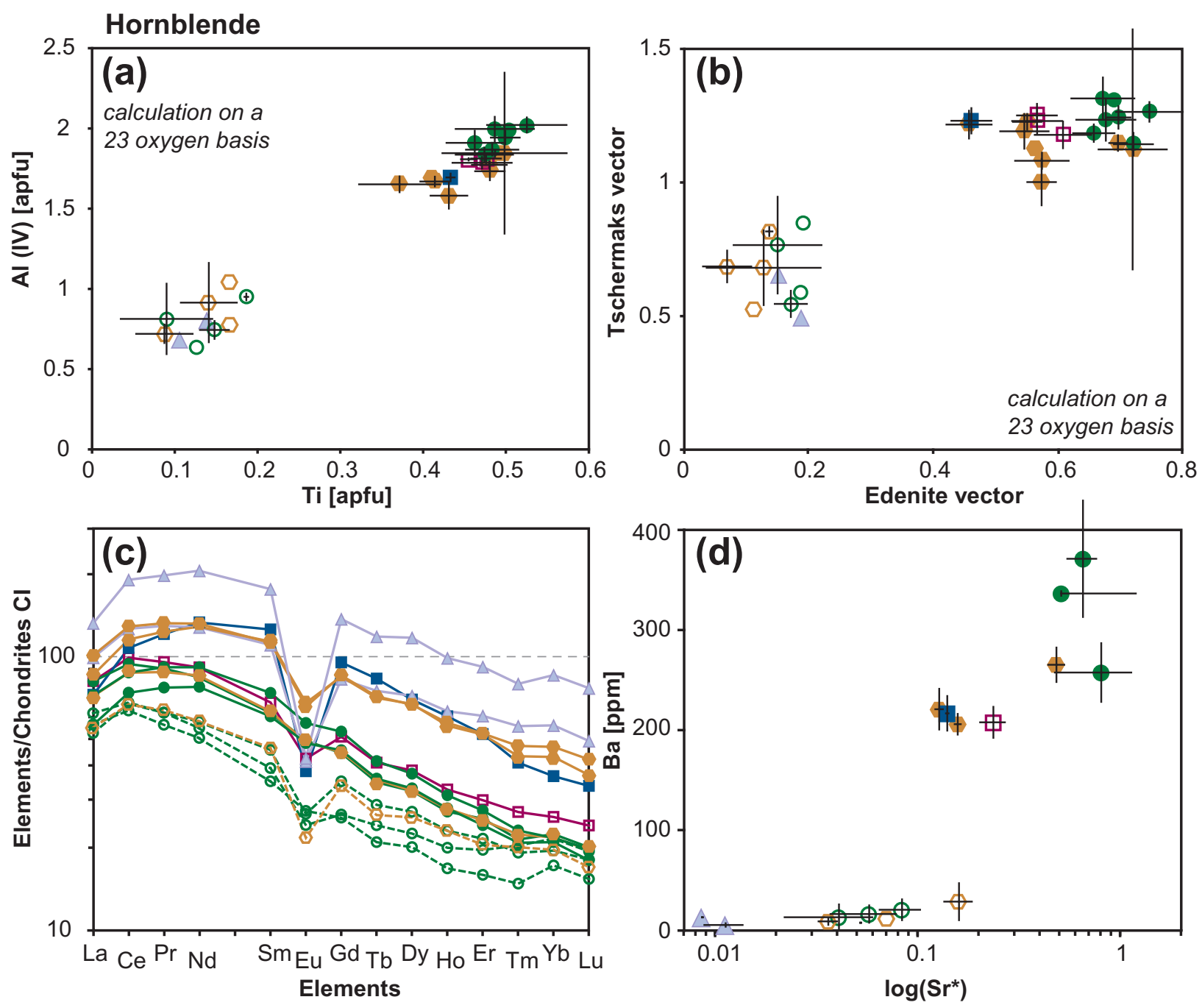

\begin{tabular}{|c|c|c|c|}
\hline Layered gabbronorite - core & - Lower Hbl-gabbro - core & Upper Hbl-gabbro - core & $\triangle$ Monzodiorite \\
\hline$\square$ Px-Hbl gabbronorite - core & O Lower Hbl-gabbro - rim & 口 Upper Hbl-gabbro - rim & \\
\hline
\end{tabular}

Fig. 14. (a, b) Average major element hornblende compositions showing two groups: (1) the Al-, Ti-, edenite- and Tschermaks-rich anhedral kaersutite cores of the lower hornblende-gabbro, poikilitic pargasite from the upper hornblende-gabbro and feeder zone gabbronorites; (2) the hornblende rims and matrix crystals from the lower and upper hornblende-gabbros and the monzodiorites. Hornblende atomic proportions are calculated on the basis of 23 oxygens, and Tschermaks and edenite vectors are calculated with a fixed $\mathrm{Fe}^{3+} / \mathrm{Fe}_{\text {tot }}=0 \cdot 3$. (c, d) The resorbed Ti-rich (kaersutite) hornblendes from the lower hornblende-gabbro display no Eu negative anomalies and have high Sr* values and Ba contents. Poikilitic Ti-rich hornblendes (pargasite) of the upper hornblende-gabbro and the feeder zone gabbronorites show discrete negative Eu and Sr anomalies. Hornblende rims and matrix amphibole in the lower and upper hornblende-gabbros and monzodiorite are Ba-poor and display distinct $\mathrm{Eu}$ and $\mathrm{Sr}$ negative anomalies. Normalization using CI chondrite of Boynton (1984).

bulk-rock $\mathrm{Mg} \#$ of the most mafic hornblende-gabbro to the most evolved monzodiorite varies from $\sim 0 \cdot 8$ to $0 \cdot 4$. To estimate the crystallized interstitial liquid fraction (CLF), the approach of Meurer \& Boudreau (1998) was applied. We calculated specific compatible and/or incompatible element (e.g. Zr) concentrations in an ideal adcumulate rock (i.e. with no interstitial melt), using the core composition and proportion of the analysed minerals and compared the result with the equilibrium parental liquid (i.e. the mafic dike composition) (details on how to calculate the CLF are given in Electronic Appendix Table 2). In the Co. Castillo lower hornblende-gabbro basal sill, the CLF that satisfies the bulk-rock $\mathrm{Zr}$ content (CLF-Zr) varies from $\sim 25-35 \%$ in the central olivine-bearing cumulate to $\sim 100 \%$ in the aphyric monzodiorite at the base of the sill. The central cumulate rocks represent $\sim 60 \mathrm{vol} . \%$ of the basal sill, giving an overall crystallinity of $\sim 40-45 \%$. Similar crystallinity values are obtained for the upper sill 

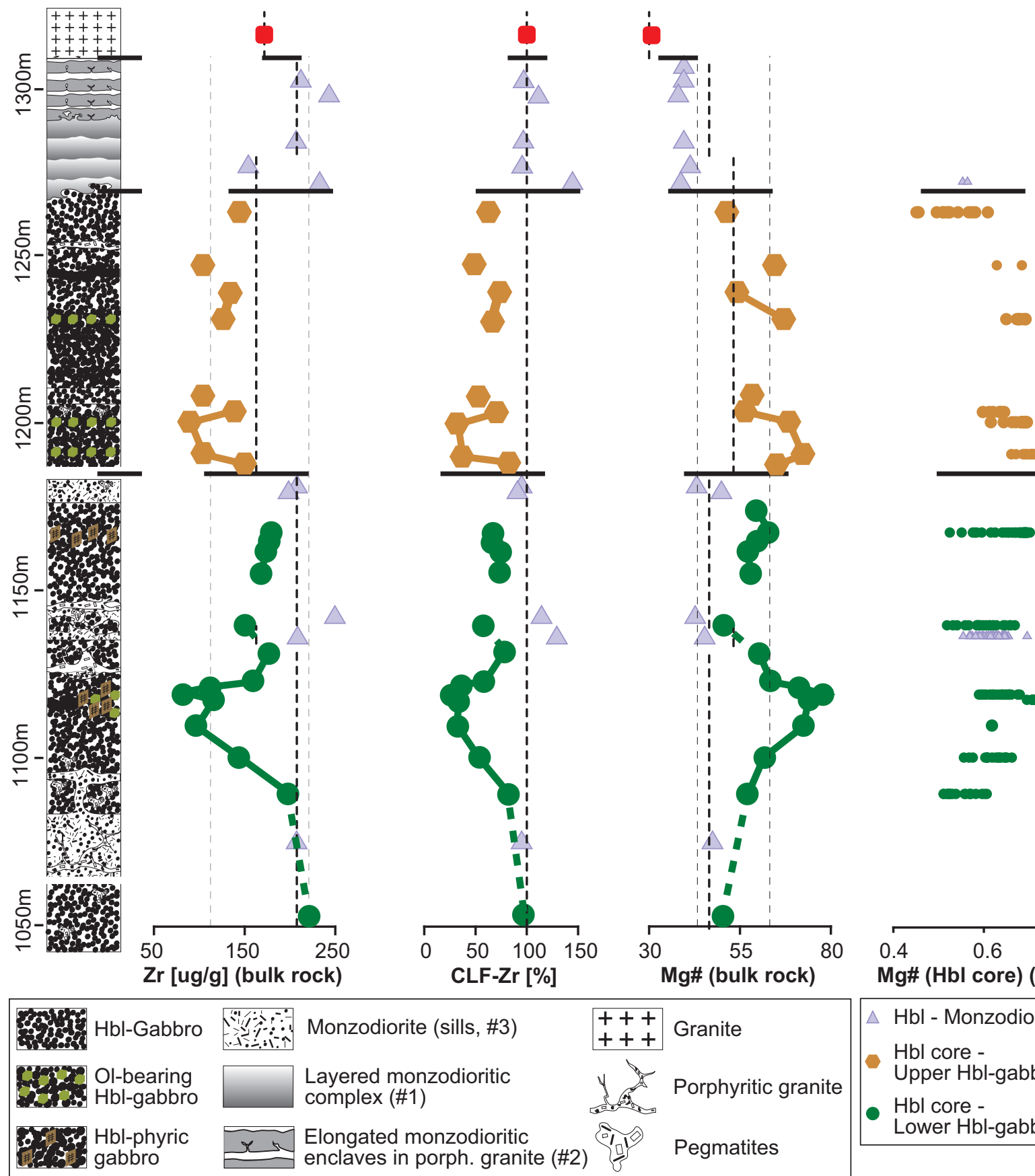

Monzodiorite (sills, \#3)
Layered monzodioritic
complex (\#1)
$\begin{aligned} & \text { Elongated monzodioritic } \\ & \text { enclaves in porph. granite (\#2) }\end{aligned}$

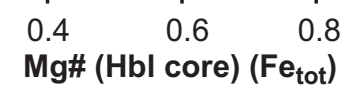

\begin{tabular}{|l|}
$\triangle$ Hbl - Monzodiorite \\
Hbl core - \\
Upper Hbl-gabbro \\
Hbl core - \\
Lower Hbl-gabbro
\end{tabular}

\begin{tabular}{|lll}
\hline BR - Lower Hbl-gabbro & $\triangle$ BR - Monzodiorite & Vertical dashed lines show \\
BR - Upper Hbl-gabbro & BR - Paine Granite & mafic dikes composition \\
\hline
\end{tabular}

Fig. 15. The bulk-rock (BR) geochemical variation across the mafic sill complex (Electronic Appendix Table 2), at Co. Castillo, shows D-shaped (Gibb \& Henderson, 1992; Latypov, 2003) symmetrical variations in $\mathrm{Mg} \#$. The hornblende core $\mathrm{Mg} \#$, and also the modal ratio of ferromagnesian minerals to feldspars, the plagioclase core anorthite content and bulk-rock Ni content (not shown) are similar, whereas the bulk-rock $\mathrm{Zr}$ content shows a negative correlation with $\mathrm{Mg} \#$. The dashed fine vertical lines correspond to the most and least primitive mafic dike composition and the dashed bold line is the averaged mafic dike composition (approaching primary liquids; Leuthold et al., 2013). The calculated CLF-Zr (crystallized liquid fraction) is an estimation of the lost $(<100 \%)$ or gained (>100\%) interstitial Zr-rich melt relatively to the parental liquid. This indicates crystal accumulation and differentiation processes. Calculations are given in the Electronic Appendix Table 2. The bulkrock chemistry of the monzodiorite sills on top of the sequence is similar to the composition of monzodiorite sills within the hornblendegabbro units. 
at Co. Castillo $(\sim 70 \%)$ and the upper hornblende-gabbro $(\sim 60 \%$ ).

In agreement with field relations and modal and textural variations within the upper hornblende-gabbro unit, bulk-rock chemical variations within single sills and between sills do not show clear chemical variations with stratigraphic height (Fig. 15), relative to the lower hornblende-gabbro units.

Monzodiorite intrusions display ductile contacts with under- or overlying hornblende-gabbros, and have CLF-Zr values of $\sim 100 \%$ suggesting emplacement of a crystal-poor magma, which does not preserve any chemical indications of further fractionation and represents the product of in situ crystallization. The studied samples have high-K calc-alkaline or shoshonitic compositions (Leuthold et al., 2013). In the summit monzodiorite unit, the two lowermost samples have a high-K calc-alkaline composition, similar to the underlying upper hornblende-gabbro. In contrast, the uppermost layered monzodiorite and the elongated monzodioritic enclaves all have a shoshonitic composition.

The hornblende $\mathrm{Mg} \#$ through the TPIC follows the evolution of the bulk-rocks (Fig. 15). Across the lower hornblende-gabbro basal sills, the $\mathrm{Mg} \#$ of the hornblende cores varies from 79-69 in the central olivine-bearing hornblende-gabbro to 60-50 in the basal olivine-free equigranular hornblende-gabbro. The chemical variability between hornblende cores in a single sample is very small, but varies from one sample to another. Only in the upper-

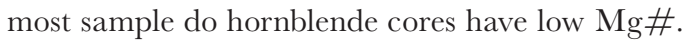

In summary, the covariation of bulk-rock and mineral chemistry within the studied vertical section suggests that the chemical variability is not determined by modal variations alone, but also indicates that the most primitive magmas were emplaced in the centre of the lower hornblende-gabbro sills.

\section{THERMOBA ROMETRY Geothermometry}

Applications of various geothermometers to the Paine mafic rocks are summarized in Electronic Appendix Table 3. Pyroxene compositions plotted in the pyroxene quadrilateral of Lindsley (1983) give $1030-860^{\circ} \mathrm{C}$ for layered gabbronorite and $1010-970^{\circ} \mathrm{C}$ for pyroxene-hornblende gabbronorite, given uncertainties of $\pm 20-30^{\circ} \mathrm{C}$ on the position of the isotherms and $\pm 20-30^{\circ} \mathrm{C}$ reflecting pyroxene analytical uncertainties. These temperatures are similar to those calculated with the calibration of Wells (1977). For the lower and upper hornblende-gabbros, no touching orthopyroxene-clinopyroxene pairs have been found. Isolated orthopyroxene and clinopyroxene have been used assuming equilibrium prior to hornblende crystallization. Estimated temperatures are $1080-990^{\circ} \mathrm{C}$ for the lower hornblende-gabbro and $1030-940^{\circ} \mathrm{C}$ for the upper hornblende-gabbro, similar to the results for other TPIC mafic units.

Hornblende-plagioclase thermometers are critical to understanding the thermal evolution of the TPIC mafic rocks; we applied the Holland \& Blundy (1994) and Ridolfi \& Renzulli (2012) Plb formalism (calibrated for $P<335 \mathrm{MPa})$. The edenite + albite $=$ richterite + anorthite equilibrium was used for quartz-free hornblende cores, and the edenite + quartz $=$ tremolite + albite equilibrium was applied to quartz-bearing hornblende rims, monzodiorite and the matrix of mafic dikes. The thermometer of Ridolfi \& Renzulli (2012) generally gives similar or higher temperatures for Ti-rich hornblende and similar or lower estimates for Ti-poor crystals. The typical calibration uncertainty for the Holland \& Blundy (1994) hornblendeplagioclase thermometers is $\pm 40^{\circ} \mathrm{C}$, and $\pm 23.5^{\circ} \mathrm{C}$ for the amphibole thermometer of Ridolfi \& Renzulli (2012). Average values for cores and rims are summarized in Table 1 and Fig. 16a and b. Calculations show that hornblende cores in the lower and upper hornblende-gabbros and pyroxene-hornblende gabbronorite and hornblende in the feeder zone layered gabbronorite crystallized at between 990 and $900^{\circ} \mathrm{C}\left(1048-915^{\circ} \mathrm{C}\right.$, using Ridolfi \& Renzulli, 2012). Monzodiorite hornblende--plagioclase pairs gave temperatures between 800 and $780^{\circ} \mathrm{C}$ $\left(710-700^{\circ} \mathrm{G}\right)$. Hornblende rims and microcrysts in the lower and upper hornblende-gabbros are compositionally similar to monzodiorite hornblende crystals, and gave crystallization temperatures of $830-770^{\circ} \mathrm{C} \quad\left(760-660^{\circ} \mathrm{G}\right)$ for the lower hornblende-gabbro and $800-770^{\circ} \mathrm{C} \quad(770-$ $690^{\circ} \mathrm{C}$ ) for the upper hornblende-gabbro, overlapping with estimates for the monzodiorites. The temperatures of hornblende cores calculated with the formalism of Ridolfi \& Renzulli (2012) are slightly higher than those obtained for pyroxene above. This could mean either that pyroxenes included in hornblende have re-equilibrated or that the Ridolfi \& Renzulli (2012) calibration overestimates hornblende core temperatures.

\section{Geobarometry}

Hornblende crystallization pressures were estimated using the empirical barometer of Ridolfi \& Renzulli (2012). Results are presented in Table 1 and Fig. 16b. Calculations for hornblende cores in the lower hornblende-gabbro indicate crystallization pressures of 430-320 MPa. Hornblende cores from the upper hornblende-gabbro and hornblende from the feeder zone gabbronorites gave values of 360-240 MPa, whereas hornblende rims and matrix crystals from the mafic sill complex hornblende-gabbros and monzodiorite crystallized at 110-60 MPa. In addition, the Al-in-hornblende barometer of Anderson \& Smith (1995), calibrated with the hornblende-plagioclase thermometer of Blundy \& Holland (1990), was also applied. The calculated pressures range from 150 to $60 \mathrm{MPa}$. This barometer calibration has an estimated error of $\pm 60 \mathrm{MPa}$. Most 
Table 1: Crystallization temperatures and pressures of the TPIC mafic samples

\begin{tabular}{|c|c|c|c|c|c|c|c|c|c|c|c|c|c|c|c|c|c|c|c|c|}
\hline & \multicolumn{3}{|c|}{ Opx-Cpx ${ }^{1}$} & \multicolumn{3}{|c|}{$\mathrm{Opx}-\mathrm{Cpx}^{2}$} & \multicolumn{3}{|c|}{$\mathrm{Hbl}-\mathrm{Plg}^{3}$} & \multicolumn{3}{|c|}{$\mathrm{Hbl}-\mathrm{Plg}^{4}$} & \multicolumn{5}{|c|}{$\mathrm{Amph}^{5}$} & \multicolumn{3}{|c|}{$\mathrm{Amph}^{6}$} \\
\hline & $T\left({ }^{\circ} \mathrm{C}\right)$ & $1 \sigma$ & $n$ & $T\left({ }^{\circ} \mathrm{C}\right)$ & $1 \sigma$ & $n$ & $T\left({ }^{\circ} \mathrm{C}\right)$ & $1 \sigma$ & $n$ & $T\left({ }^{\circ} \mathrm{C}\right)$ & $1 \sigma$ & $n$ & $T\left({ }^{\circ} \mathrm{C}\right)$ & $1 \sigma$ & $P(\mathrm{kbar})$ & $1 \sigma$ & $n$ & $P($ kbar $)$ & $1 \sigma$ & $n$ \\
\hline \multicolumn{21}{|c|}{ Layered gabbronorite (feeder zone) } \\
\hline 08JL435 & 924 & \pm 66 & 5 & 971 & \pm 35 & 5 & 944 & \pm 8 & 4 & - & - & & 916 & \pm 4 & $2 \cdot 7$ & $\pm 0 \cdot 1$ & 4 & - & - & \\
\hline \multicolumn{21}{|c|}{ Pyroxene-hornblende gabbronorite (feeder zone) } \\
\hline 04JM36 & 970 & \pm 0 & 2 & 948 & \pm 2 & 2 & 957 & \pm 16 & 19 & - & - & & 1002 & \pm 20 & $3 \cdot 2$ & $\pm 0 \cdot 1$ & 19 & - & - & \\
\hline 05JM4 & - & - & & - & - & & 987 & \pm 1 & 2 & - & - & & 989 & \pm 10 & $3 \cdot 1$ & $\pm 0 \cdot 0$ & 2 & - & - & \\
\hline 05JM9 & 997 & \pm 15 & 3 & 929 & \pm 5 & 3 & 940 & \pm 10 & 17 & - & - & & 990 & \pm 13 & $3 \cdot 3$ & $\pm 0 \cdot 2$ & 16 & - & - & \\
\hline \multicolumn{21}{|c|}{ Lower hornblende-gabbro (mafic sill complex) } \\
\hline 07JL99 & - & - & & - & - & & 939 & \pm 7 & 10 & - & - & & 999 & \pm 13 & $3 \cdot 5$ & $\pm 0 \cdot 2$ & 8 & - & - & \\
\hline 07JL101 & - & - & & - & - & & 951 & \pm 8 & 14 & - & - & & 1014 & \pm 12 & $4 \cdot 0$ & \pm 0.5 & 16 & - & - & \\
\hline 07JL149 & 990 & \pm 0 & 2 & 853 & \pm 4 & 2 & 974 & \pm 21 & 16 & - & - & & 1047 & \pm 12 & $3 \cdot 8$ & $\pm 0 \cdot 3$ & 16 & - & - & \\
\hline 07JL150 & - & - & & - & - & & 957 & \pm 15 & 17 & - & - & & 1035 & \pm 12 & $4 \cdot 3$ & $\pm 0 \cdot 3$ & 18 & - & - & \\
\hline 07JL156 = 08JL383 & - & - & & - & - & & 957 & \pm 17 & 39 & - & - & & 1044 & \pm 23 & $4 \cdot 3$ & $\pm 0 \cdot 3$ & 51 & - & - & \\
\hline 08JL372 & 1075 & \pm 5 & 2 & - & - & & 966 & n.a. & 1 & - & - & & 961 & n.a. & $4 \cdot 0$ & n.a. & 1 & - & - & \\
\hline 08JL375 & - & - & & - & - & & 952 & \pm 18 & 22 & - & - & & 960 & \pm 28 & $3 \cdot 2$ & $\pm 0 \cdot 3$ & 22 & - & - & \\
\hline \multicolumn{21}{|c|}{ Lower hornblende-gabbro, matrix (mafic sill complex) } \\
\hline 07JL156 = 08JL383 & - & - & & - & - & & - & - & & 771 & n.a & 1 & 760 & n.a. & 0.9 & n.a. & 1 & 1.5 & n.a. & 1 \\
\hline 08JL372 & - & - & & - & - & & 736 & 21 & 2 & - & - & & 741 & \pm 61 & 0.9 & $\pm 0 \cdot 3$ & 3 & - & - & \\
\hline 08JL375 & - & - & & - & - & & - & - & & 801 & n.a & 1 & 655 & \pm 26 & 0.6 & $\pm 0 \cdot 1$ & 9 & 0.8 & $\pm 0 \cdot 3$ & 11 \\
\hline \multicolumn{21}{|c|}{ Upper hornblende-gabbro (mafic sill complex) } \\
\hline 05JM29 & - & - & & - & - & & 947 & \pm 5 & 10 & - & - & & 979 & \pm 8 & $3 \cdot 2$ & $\pm 0 \cdot 1$ & 11 & - & - & \\
\hline 07JL123 & - & - & & - & - & & 902 & \pm 17 & 18 & - & - & & 915 & \pm 15 & $2 \cdot 5$ & $\pm 0 \cdot 1$ & 17 & - & - & \\
\hline 07JL158 & 1000 & n.c & 1 & 908 & n.a. & 1 & 987 & \pm 10 & 17 & - & - & & 1048 & \pm 19 & $3 \cdot 6$ & $\pm 0 \cdot 2$ & 17 & - & - & \\
\hline 07JL160 & - & - & & - & - & & 937 & \pm 9 & 5 & - & - & & 946 & \pm 14 & $2 \cdot 7$ & $\pm 0 \cdot 0$ & 5 & - & - & \\
\hline 07JL162 & 995 & \pm 35 & 2 & - & - & & 940 & \pm 16 & 7 & - & - & & 959 & \pm 9 & $2 \cdot 6$ & $\pm 0 \cdot 1$ & 8 & - & - & \\
\hline 07JL164 & - & - & & - & - & & 967 & n.a. & 1 & - & - & & 1001 & n.a. & 3.0 & n.a. & 1 & - & - & \\
\hline 08JL388 & 985 & \pm 63 & 2 & - & - & & 977 & \pm 11 & 22 & - & - & & 1014 & \pm 16 & $3 \cdot 4$ & $\pm 0 \cdot 2$ & 22 & - & - & \\
\hline 08JL389 & - & - & & - & - & & 915 & \pm 18 & 12 & - & - & & 927 & \pm 24 & $2 \cdot 4$ & $\pm 0 \cdot 2$ & 12 & - & - & \\
\hline \multicolumn{21}{|c|}{ Upper hornblende-gabbro, matrix (mafic sill complex) } \\
\hline 05JM29 & - & - & & - & - & & - & - & & 828 & \pm 28 & 4 & 767 & \pm 78 & $1 \cdot 1$ & $\pm 0 \cdot 3$ & 3 & - & - & \\
\hline 07JL123 & - & - & & - & - & & - & - & & 803 & n.a & 1 & 762 & \pm 13 & $1 \cdot 0$ & $\pm 0 \cdot 1$ & 5 & - & - & \\
\hline 07JL164 & - & - & & - & - & & - & - & & 766 & \pm 4 & 2 & 768 & \pm 8 & 0.8 & $\pm 0 \cdot 0$ & 3 & - & - & \\
\hline 08JL388 & - & - & & - & - & & - & - & & 781 & n.a & 1 & 757 & \pm 12 & 0.8 & $\pm 0 \cdot 1$ & 4 & - & - & \\
\hline 08JL389 & - & - & & - & - & & - & - & & - & - & & 689 & \pm 11 & 0.6 & $\pm 0 \cdot 0$ & 9 & $0 \cdot 7$ & 0.3 & 9 \\
\hline \multicolumn{21}{|c|}{ Monzodiorite (mafic sill complex) } \\
\hline 07JL165 & - & - & & - & - & & - & - & & - & - & & - & - & - & - & & - & - & \\
\hline 08JL376 & - & - & & - & - & & - & - & & 796 & \pm 17 & 6 & 700 & \pm 33 & 0.7 & $\pm 0 \cdot 1$ & 35 & $0 \cdot 6$ & 0.6 & 34 \\
\hline 08JL385 & - & - & & - & - & & - & - & & - & - & & - & - & - & - & & - & - & \\
\hline 08JL390 & - & - & & - & - & & - & - & & 776 & n.a & 1 & 707 & n.a. & 0.7 & n.a. & 1 & - & - & \\
\hline
\end{tabular}

Thermometers applied to the TPIC mafic samples averaged mineral compositions. This table is also available as Electronic Appendix Table 3.

${ }^{1}$ Orthopyroxene-clinopyroxene (Lindsley, 1983).

${ }^{2}$ Orthopyroxene-clinopyroxene (Wells, 1977).

${ }^{3}$ Edenite + albite $=$ richterite + anorthite (Holland \& Blundy, 1994; quartz-free thermometer).

${ }^{4}$ Edenite + quartz = tremolite + albite (Holland \& Blundy, 1994; quartz-bearing thermometer).

${ }^{5}$ Amphibole [Ridolfi \& Renzulli, 2012; using equation (P1b)]. ${ }^{6}$ Amphibole (Anderson \& Smith, 1995). 
Hornblende-plagioclase thermometry

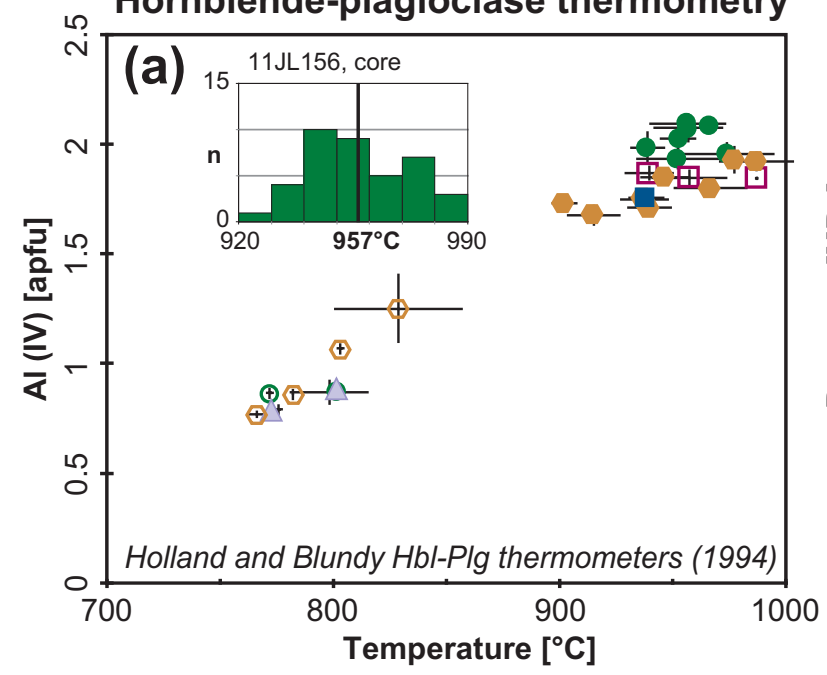

Hornblende thermobarometry

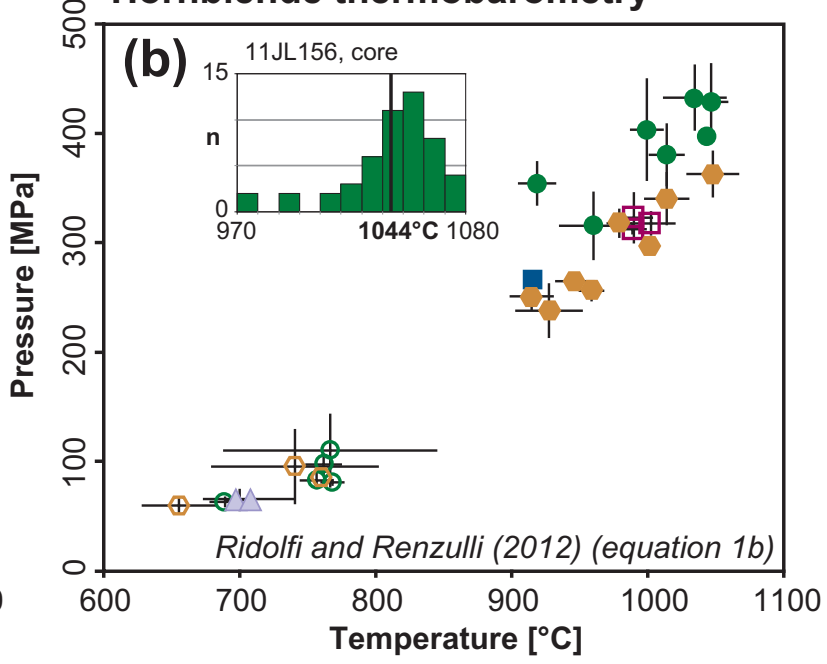

Layered gabbronorite - core Lower Hbl-gabbro - core $\square \mathrm{Px}-\mathrm{Hbl}$ gabbronorite - core $\mathrm{O}$ Lower Hbl-gabbro - rim

Upper Hbl-gabbro - core $\triangle$ Monzodiorite
$\square$ Upper Hbl-gabbro - rim

Fig. 16. (a) Thermobarometry for hornblende-plagioclase pairs (Holland \& Blundy, 1994). The quartz-free formulation (edenite + albite $=$ richterite + anorthite) was used for hornblende cores and plagioclase inclusions and the quartz-present formulation (edenite + quartz $=$ tremolite + albite) was used for hornblende rims and matrix crystals, paired with plagioclase. The average hornblende core crystallization temperature is identical for all mafic units and ranges between 990 and $900^{\circ} \mathrm{C}$. Monzodiorite matrix crystals and lower and upper hornblende-gabbros hornblende rims and matrix crystals crystallized at $830-770^{\circ} \mathrm{C}$. The $1 \sigma$ error bars represent mineral composition variability, but the $\pm 40^{\circ} \mathrm{C}$ calibration uncertainty is not shown. The histogram shows the variability of single calculated temperatures for one lower hornblende-gabbro sample (11JL156). Mean values were considered (also very close to median values). (b) Similar calculations using the amphibole thermobarometer of Ridolfi \& Renzulli (2012) result in identical to slightly higher temperatures for hornblende cores, and similar to slightly lower temperatures for hornblende rims and matrix crystals. Hornblende cores crystallized at $\sim 300 \mathrm{MPa}$ (both gabbronorites and upper hornblende-gabbro) to $\sim 400 \mathrm{MPa}$ (lower hornblende-gabbro) and the hornblende rims and matrix crystals at $\sim 90 \mathrm{MPa}$. The equation (1b) of Ridolfi \& Renzulli (2012), calibrated for pressure lower than $335 \mathrm{MPa}$, was used. The $1 \sigma$ error bars are shown, but the calibration uncertainty of $\pm 23 \cdot 5^{\circ} \mathrm{C}$ is not.

samples are simultaneously saturated in quartz, K-feldspar, titanite, biotite, $\mathrm{Fe}-\mathrm{Ti}$ oxide, melt and fluid, in addition to plagioclase and hornblende. These calculated emplacement pressures are in good agreement with other petrological constraints; for example, from contact-metamorphic assemblages, which yield a pressure of $75 \pm 20 \mathrm{MPa}$ (Putlitz et al., 2001; Baumgartner et al., 2007).

We conclude that interstitial liquids within the hornblende-gabbros and the monzodiorite, and more generally the mafic sill complex, crystallized at about $70 \mathrm{MPa}$. However, this is not the case for the pargasite and kaersutite and their olivine and pyroxene inclusions, which crystallized at distinctly higher pressures, estimated to 300-400 MPa. Early crystals thus formed at a mid-crustal level or deeper and were then transported to the shallow mafic sill complex as a crystal mush. We showed above that such crystals are more abundant and more mafic in the sill centre than in the sill border. Study of these crystals has considerable importance for understanding the growth mechanisms of the Torres del Paine laccolith. This point will be discussed in more detail below, using mineral and rock textures.

\section{DIS C USS I O N \\ Origin of Torres del Paine hornblende crystals}

Distinctly higher crystallization pressures and temperatures were estimated for brown hornblende cores than for green hornblende rims and matrix crystals (Fig. 16a and b). The crystallization conditions of the latter are similar to those of the monzodiorite hornblende $\left(\sim 90 \mathrm{MPa},<830^{\circ} \mathrm{C}\right)$. In the lower hornblende-gabbro, high-temperature $\left(>900^{\circ} \mathrm{C}\right)$ hornblende cores crystallized prior to plagioclase, as suggested by the absence of plagioclase inclusions, and the absence of $\mathrm{Eu}$ and $\mathrm{Sr}$ negative anomalies. In the upper hornblende-gabbro and pyroxene-hornblende gabbronorite, poikilitic textures and trace element chemistry are consistent with coprecipitation of hornblende and plagioclase.

Hornblende saturation in fractionating calc-alkaline magmas depends mainly on the crystallization pressure, magmatic $\mathrm{H}_{2} \mathrm{O}$ content, and the bulk $\mathrm{Na}_{2} \mathrm{O}$ content of the silicate melt (e.g. Sisson \& Grove, 1993). The difference in the crystallization sequence of the lower hornblende- 
gabbro relative to the upper hornblende-gabbro and feeder zone gabbronorites probably results from a combination of these effects. Indeed, the lower hornblende-gabbros generally have higher alkaline contents and are shoshonitic on a $\mathrm{K}_{2} \mathrm{O}$ vs $\mathrm{SiO}_{2}$ discrimination diagram, whereas the upper hornblende-gabbro and pyroxene-hornblende gabbronorite plot in the high-K calc-alkaline field (Leuthold et al., 2013). Additionally, estimates of crystallization pressure (Fig. 16b) show that the hornblende cores in the lower hornblende-gabbro crystallized in a distinctly deeper reservoir. The late, interstitial crystallization of hornblende in the layered gabbronorite indicates the less $\mathrm{H}_{2} \mathrm{O}$-rich composition of the parental liquid.

Textural evidence of hornblende destabilization during the final stages of crystallization is a main feature of the lower hornblende-gabbro. It is highlighted by biotite overgrowth and hornblende resorption textures. It has been shown experimentally that hornblende becomes unstable at low pressure for a wide variety of compositions (e.g. Rutherford \& Devine, 2003), and therefore rapid nearisothermal decompression causes hornblende to partially dissolve (e.g. Blundy \& Cashman, 2001). If decompression occurs within the stability field of biotite, hornblende cores are overgrown by biotite, indicating peritectic replacement of hornblende by biotite. This is observed in the K-rich lower hornblende-gabbros, but not in the more K-poor upper hornblende-gabbro (Leuthold et al., 2013), consistent with the experimental evidence for enhanced thermal stability of biotite in $\mathrm{K}_{2} \mathrm{O}$-rich magmas (Molina et al., 2009) and consistent with the experimental observations of biotite formation through the reaction of hornblende with a K-rich melt (Sisson et al., 2005). We conclude that hornblende resorption textures in the Paine mafic complex record decompression accompanied by peritectic biotite crystallization.

\section{Discussion of plagioclase textures}

Three types of plagioclase textures have been identified in the Torres del Paine mafic rocks. Partially resorbed cores (An60-An30) are overgrown by subidiomorphic plagioclase (An70). In the mafic sill complex, the cores are normally zoned, with albite-rich rims, compositionally similar to those in the monzodiorite. The complex zoning patterns are preserved during cooling of the gabbros, owing to slow diffusion kinetics. A variety of parameters including temperature, pressure, melt water content and melt compositional variations have been proposed to cause complex plagioclase zoning (e.g. Blundy \& Shimizu, 1991; Kuritani, 1998; Berlo et al., 2007; Ginibre et al., 2007; Streck, 2008; Hoshide \& Obata, 2010).

Resorbed patchily zoned cores, overgrown by An-rich plagioclase, may either be xenocrysts or antecrysts (Miller et al., 2007), as the first plagioclase to crystallize in all gabbros is $\sim$ An70. Resorbed plagioclase is absent from the lower hornblende-gabbros, which display the highest magmatic $\mathrm{H}_{2} \mathrm{O}$ contents and which also are the least crustally contaminated rocks of the entire TPIC (Leuthold et al., 2013), suggesting that they might be xenocrysts.

An75-55 plagioclase is included in hornblende in the upper hornblende-gabbro, pyroxene-hornblende gabbronorite, and rarely lower hornblende-gabbro, as well as in pyroxene from the layered gabbronorite. Thermobarometry calculations indicate high temperatures $\left(>900^{\circ} \mathrm{C}\right)$ and elevated pressures (>200 MPa) of crystallization. However, plagioclase crystals that are not included in brown hornblende or pyroxene display discrete resorption textures and/or reverse zoning and may be cracked (Fig. 10). Cracked cores in plagioclase may indicate decompression at $\mathrm{H}_{2} \mathrm{O}$-unsaturated conditions (e.g. Blundy \& Shimizu, 1991). Combined with the evidence from hornblende textures, we interpret the An-rich plagioclase cores to originate from a magma reservoir deeper than the actual exposed crustal level of the TPIC.

Subsequent normal zoning is observed in plagioclase in the gabbronorites and hornblende-gabbros. Blundy \& Shimizu (1991) proposed that chemical and textural discontinuities in plagioclase are consistent with mixing of calcic cores into derivative felsic melts, either by crystal retention or by cumulate disruption.

Additional factors that may influence the normal zoning of plagioclase include the following.

(1) Rapid cooling and enhanced crystallization may contribute to rapid differentiation and crystallization of more albitic rims together with hornblende and/or biotite (e.g. Grove \& Donnelly-Nolan, 1986; Sisson \& Grove, 1993). Different equilibration temperatures are determined between coexisting Ti-rich hornblende and An-rich plagioclase, and matrix Mg-rich hornblende and An-poor plagioclase pairs. Rapid cooling may be explained by magma emplacement into a shallow crust sill complex. This process has probably contributed to plagioclase normal zoning in the upper hornblende-gabbro (co-crystallization with hornblende and biotite) and lower hornblende-gabbro (co-crystallization with biotite alone in the first stage).

(2) As discussed above, Ti-rich hornblende and its respective inclusions crystallized in a deeper magma reservoir, whereas hornblende rims probably formed at the emplacement level of the mafic sill complex. Plagioclase will be normally zoned during decompression-induced crystallization, if the magma is water-saturated. However, water saturation during decompression is probably unrealistic for the case of the TPIC, as it would be associated with an enormous driving force for crystallization, especially of plagioclase, owing to undercooling (Cashman \& Blundy, 2000). As a consequence, the magmas would probably be too viscous to rise to shallow levels in the crust. Additionally, the magma crystallinity rapidly increases once hornblende saturation has been reached (e.g. Barclay \& Carmichael, 2004). From 55 vol. \% crystals (varying 
with deformation), the magma viscosity is strongly increased and becomes 'rigid' at a solid fraction exceeding 70 vol. \% (e.g. Vigneresse et al., 1996; Mader et al., 2013). According to our CLF-Zr calculations, the amount of trapped liquid in the hornblende-gabbro sills varied from $\sim 25$ to $\sim 100 \%$, from the central cumulate to the sill margins. We estimate the overall crystallinity of the Paine mafic magmas at the time of emplacement in the mafic sill complex to be $\sim 40 \%$. Thus, we argue that formation of normal zoning in plagioclase in the Torres del Paine gabbros is unlikely to be related to decompression-induced crystallization.

\section{Magma emplacement in the feeder zone}

The feeder zone gabbronorite intrusions have been emplaced vertically, with a WSW-ENE orientation. Similar U-Pb ID-TIMS zircon ages indicate simultaneous crystallization of both gabbronorite units (Leuthold et al., 2012). Internal contacts between layered gabbronorite stocks or with pyroxene-hornblende gabbronorite can be either ductile or brittle. This possibly highlights variations in the host layered gabbronorite temperature (and interstitial melt content) and deformation time scale (Dingwell, 2006). The gabbronorite magmas clearly intruded as successive stocks, forming sheath folds. Below we discuss the particular textures of the feeder zone layered gabbronorite, considering (1) its hornblende-poor nature and (2) the formation of the leucocratic plagioclase-rich layers.

(1) The lack of interstitial minerals, evidenced by the scarcity of hornblende, plagioclase rims and biotite, indicates that interstitial liquid was efficiently expelled from the layered gabbronorites, and to a lesser extent from the pyroxene-hornblende gabbronorite. This is also confirmed by positive Eu and Sr anomalies in bulk-rocks, along with complementary negative $\mathrm{Sr}$ and $\mathrm{Eu}$ anomalies in the extracted granitic liquids (Leuthold et al., 2013). As discussed above, olivine and clinopyroxene crystals are overgrown by Ti-rich brown hornblende, indicating peritectic, hornblende-forming reactions such as olivine + liquid $=$ hornblende, or clinopyroxene + liquid $=$ hornblende. However, the near absence of hornblende, and thus the preservation of unreacted olivine and clinopyroxene, constrains interstitial melt extraction at conditions close to or prior to hornblende saturation; for example, higher than about $950^{\circ} \mathrm{C}$ and pressures exceeding $270 \mathrm{MPa}$ (Table 1, Fig. 16). Such high temperatures for the extraction of interstitial granitic magmas are in agreement with those inferred from the contact aureole in the granitic sill complex (Bodner, 2013).

(2) After extraction of most of the interstitial liquid, the gabbronorite remained partially molten and was deformed during further ascent (Fig. 7a). Feeder systems and volcanic conduits are highly dynamic environments, with localized strain (Lavallée et al., 2012). Caricchi et al. (2007) and Pistone et al. (2012, 2013) explained segregation of interstitial liquid from cumulates along an interconnected porous network formed by high shear rates. Experiments show that melt channels may form parallel to the applied strain or as conjugate fractures (Holtzman et al., 2005; Pistone et al., 2012). There is no evident crystal plastic deformation texture in the pyroxene-rich layers and shearing might focus in the oriented melt-rich layers from which plagioclase, \pm hornblende, \pm biotite eventually crystallized. Plagioclase primocrysts will eventually be concentrated in the more $\mathrm{H}_{2} \mathrm{O}$-rich liquid (e.g. Hoshide \& Obata, 2010). The estimated liquid fraction responsible for the layered gabbronorite bulk-rock $\mathrm{Zr}$ concentration (CLF-Zr; Meurer \& Boudreau, 1998) is only about 20\%. Thus, compaction and further melt loss certainly occurred during magma ascent and at the emplacement level, when new stocks were emplaced. In the pyroxene-hornblende gabbronorites, hornblende is more abundant, replacing pyroxene and olivine. Based on geochemical similarities, Leuthold et al. (2013) proposed that the pyroxene-hornblende gabbronorites crystallized from a similar, but more hydrous magma, with variable amounts of trapped interstitial melt. Textures recording super-solidus deformation are less evident than in the layered gabbronorite. By analogy, we suggest that magma emplacement processes were similar for both feeder zone mafic units. The magma ascent and emplacement model is illustrated in Fig. 17.

Based on fractional crystallization models and identical high-precision $\mathrm{U}-\mathrm{Pb}$ zircon emplacement ages, Leuthold et al. (2013) proposed a genetic link between the feeder zone gabbronorites and the Unit I granite (Almirante Granite) that forms the topmost unit of the granite sill complex. The model calculations considered $\sim 70 \%$ gabbronorite to pyroxene-hornblende gabbronorite cumulate fractionation from an estimated high-K calc-alkaline basaltic trachyandesitic parent magma composition. The small volume of mafic cumulates exposed in the feeder zone $\left(\sim 1 \mathrm{~km}^{3}\right.$, Leuthold et al., 2012) relative to the estimated volume of the Unit I granite $\left(\sim 18 \mathrm{~km}^{3}\right)$ suggests that an important volume of mafic cumulates $\left(\sim 60 \mathrm{~km}^{3}\right)$ must be stored in a deeper magma reservoir and along the feeder conduit. Based on the pressure and temperature estimates discussed above, we infer that the granite I unit segregated from its (feeder zone) gabbronorite cumulate at $T \sim 950^{\circ} \mathrm{C}$ and $P>270 \mathrm{MPa}$. The feeder zone gabbros were probably mobilized in the aftermath of granite I emplacement and intense super-solidus shearing formed the fine-grained alternations of pyroxene- and plagioclaserich layers. The late-stage aplitic veins formed at the emplacement level. They occur typically at the contact between pyroxene gabbronorite and intensely deformed layered gabbronorite (Fig. 3d). Thus, we propose that they result from interstitial liquid segregation from compacting gabbronorite cumulates, during the emplacement of subsequent magma stocks. Shearing was responsible for fracturing the low-porosity pyroxene-hornblende gabbronorite host, and felsic interstitial melt was segregated within and along the opened fractures. 


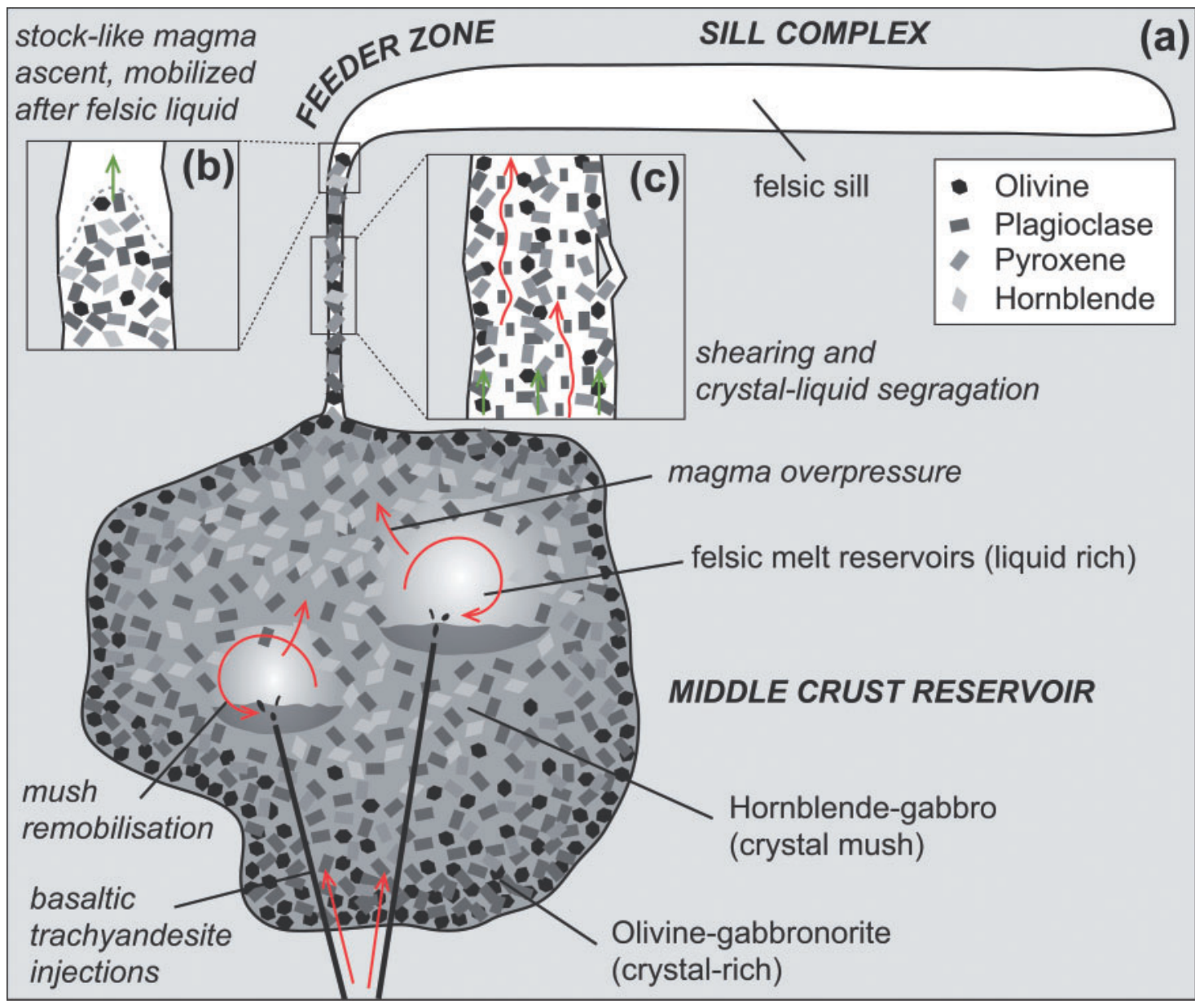

Fig. 17. (a) A simplified illustration showing the general process of magma rejuvenation and overpressurization by magma infill in a deep magma reservoir, crystal mush remobilization, ascent in large conduits and sill emplacement in a shallow intrusion. Differentiated crystalpoor felsic liquid is extracted from the middle crust magma reservoir and emplaced as a sill-like laccolith. (b) Stock-like ascent of mafic cumulate (e.g. layered gabbronorite, pyroxene-hornblende gabbronorite), probably mobilized in the aftermath of felsic magma emplacement. (c) Strain partitioning and continuing efficient extraction of interstitial liquid from the rising mafic crystal mush, resulting in bimodal syn-magmatic magmas.

\section{Magma emplacement in the mafic sill complex (Braided Sill Model)}

The vertical succession of lower hornblende-gabbro, upper hornblende-gabbro and monzodiorite remains constant throughout the mafic sill complex. The number and size of sills varies along a north-south profile, but seems to be generally constant along west-east transects, with smallscale variations that are caused by later emplacement of porphyritic granite, monzodioritic sills, and olivinebearing hornblende-gabbro lenses or dikes. The mafic sill complex is thus built up of a succession of braided, channelled sills and fingers (Fig. 18), over $\sim 41 \mathrm{kyr}$ (Leuthold et al., 2012). Magma injection is likely to rejuvenate the host material, so that contacts may be ductile, possibly mixed or eroded. Pollard et al. (1975) proposed that horizontal sheet-like intrusions (sills) terminate as offset fingers. The exact location of the feeding system of the mafic sill complex is currently unknown but we assume that it is located below the Glaciar los Perros. New magma would be forced to accrete under the deflected, rigid older Unit III granite (Gudmundsson, 2011; Menand, 2011).

The lower hornblende-gabbro basal sill textures and chemical profiles (Fig. 15) are crucial to understand magma emplacement dynamics within the mafic sill complex. The lower sill shows accumulation of primitive crystals (high $\mathrm{Mg} \#$, high $\mathrm{Ni}$ content) in a sparse felsic matrix in its centre. The margins are fine-grained, equigranular hornblende-gabbro to monzodiorite associated with pegmatites. The estimated minimum melt fraction at the time of emplacement of single sills was $\sim 60$ vol. $\%$, taking into account post-emplacement processes such as 


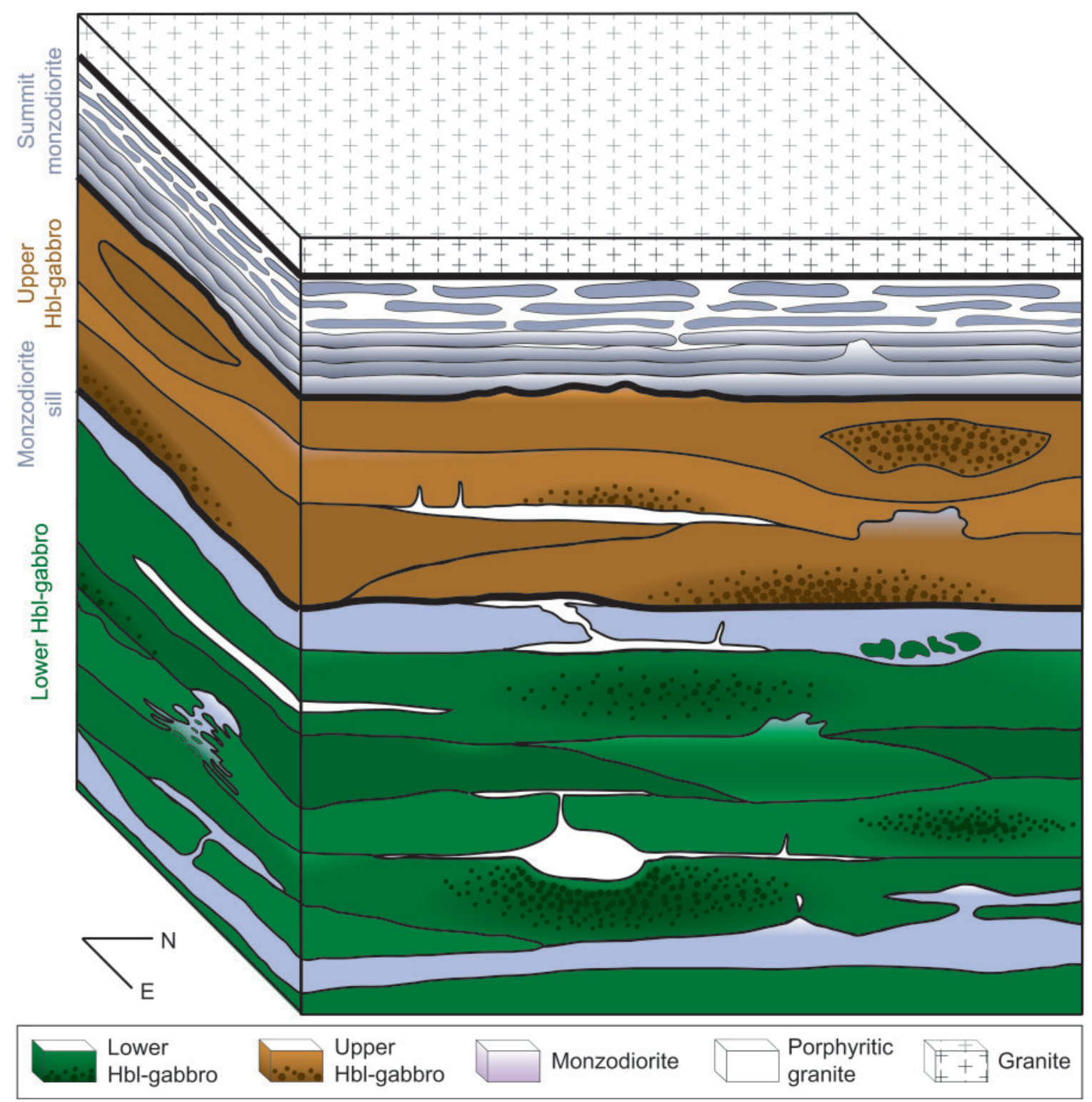

Fig. 18. A 3D block diagram illustrating the model of a braided sill complex to explain the construction of the mafic sill complex. The internal structures and contacts of sills, deduced from field and petrographical observations, are shown. Magma batches flow eastwards in magma channels, accreted on top of, beneath or within previously emplaced sills. Dark dots show the location of cumulate rocks (evidenced by hornblende macrocrysts).

compaction and formation of small diapirs. The assumption of minimal melt loss is supported by the absence of distinct cumulate geochemical signatures in the hornblende-gabbros (Leuthold et al., 2013). Transported crystals become progressively less primitive and less abundant towards the sill borders. This results in a symmetrical vertical variation in modal mineralogy and chemistry, which has been termed a D-shaped compositional profile (e.g. Gibb \& Hendersen, 1992). Various models have been proposed to explain the origin of such profiles, as follows.
(1) Aarnes et al. (2008) presented a model involving post-emplacement porous melt flow induced by thermal stresses, in which differentiated melt is sucked by the crystallizing fluid into the underpressured sill margins. In the Torres del Paine margins CLF-Zr are not more evolved than the estimated parental liquid. Nevertheless, porous flow of interstitial melt can account for the progressive transition from An-rich cores to An-poor rims in some plagioclase crystals and for the formation of pegmatites. This mechanism might then contribute to the observed 
plagioclase zoning and the observed draining of sills by small pegmatites.

(2) Irvine (1980) suggested that the emplacement velocity is presumably higher in sill centres than along their borders. Flow differentiation results in large particles being segregated towards the centre of the sill. Flow differentiation has been proposed for the origin of D-shaped profiles (Latypov, 2003) and such a model is consistent with the concentration of early formed crystals and crystal aggregates in the centre of the sills.

(3) Gibb \& Henderson (2006) proposed a multi-stage injection model of variable melts, with different crystal fractions and compositions. In Torres del Paine there is evidence for intrusion of geochemically different magmas, with different alkali and water contents (Leuthold et al., 2013), and mineralogy. The structure of the lower hornblende-gabbro lower sill may be explained by intrusion of melts varying from trachybasalt, chilled along the sill margins, to a more mafic, crystal-bearing magma emplaced in the centre.

(4) We argue here that the observed D-shaped compositional profiles result from dynamic processes during magma ascent. The structure of the sill complex may reflect different magma ascent velocities. The first magma emplaced was crystal-poor rhyolite that was extracted from a magma reservoir similar in composition to the feeder zone gabbronorites (Leuthold et al., 2013). This was followed by a more viscous crystal-rich magma comprising remobilized mafic crystal mush. This model provides an alternative to those of Irvine (1980) and Gibb \& Hendersen (1992). We consider that the effective viscosity of crystal mushes and consequent sorting and compositional changes are more important during magma ascent than during sill emplacement.

Hypotheses (1), (3) and (4) can explain the sill texture and chemistry, as well as the occurrence of olivine-bearing hornblende-gabbro lenses in the mafic parts of the Torres del Paine mafic sill complex. Although mineral-melt segregation is well documented from field observations, crystal-rich and crystal-poor zones probably formed during magma ascent and crystals were further sorted during sill emplacement in a complex interplay of sorting and crystallization (Fig. 17). Further in situ gravitationally induced readjustments or compaction, associated with crystal settling and felsic melt segregation (felsic pipes, pegmatites, monzodiorite diapirs), have partially blurred the original sill structure.

At the top of the mafic sill complex, along vertical profiles, layered monzodiorite (\#1) progressively changes to elongated monzodioritic enclaves (\#2) within porphyritic granite. Ductile contacts become gradually more brittle, because of the temperature gradient between the older and colder granitic complex and the younger mafic complex (Leuthold et al., 2012). Monzodioritic and porphyritic granite magmas are clearly synchronous with the mafic complex; various hypotheses may be proposed to explain the origin of the summit monzodiorite and the porphyritic granite and their textures, as follows.

(1) In Co. Castillo, the lowermost layered monzodiorite samples belong to the same high-K calc-alkaline differentiation trend as the underlying upper hornblende-gabbro. The two magma types coexisted, as revealed by mingling and mixing textures and identical $\mathrm{U}-\mathrm{Pb}$ zircon ages (Leuthold et al., 2012). In Co. Tiburon, there is good evidence for expelled monzodioritic liquid from the upper hornblende-gabbro cumulate, mingling with the overlying crystal mush on its way to the top of the mafic sill complex. We thus conclude that part of the summit monzodiorite magma was expelled from the compacting hornblendegabbro. Leuthold et al. (2013) successfully modelled the alkali-poor monzodiorite differentiation from the related upper hornblende-gabbro.

(2) However, evidence for intrusive high-K calc-alkaline and shoshonitic monzodiorite sills within the hornblendegabbros also exists. Such sills could have intruded partially crystallized granite, forming elongated, quenched and dismembered enclaves, in a similar way to that described by Sisson et al. (1996). The porphyritic granite may be a small volume of expelled felsic liquid from the mafic sill complex, accumulated below the older TPIC granite cap. However, AFG models presented by Leuthold et al. (2013) fail to explain the link between hornblende-gabbro and granite. Alternatively, the porphyritic granite could be an additional granitic unit, under-accreted at the base of the granitic complex (Michel et al., 2008; Leuthold et al., 2012).

\section{The magmatic plumbing system of the Torres del Paine intrusive complex}

We propose a schematic $P-T$ reconstruction of the TPIC system in Figs 19 and 20, which illustrate a simplified model of TPIC evolution. Mineral chemistry, textures and thermobarometry calculations indicate that three different crystallization levels can be distinguished. Olivine in the feeder zone gabbronorites crystallized from an already differentiated melt, suggesting fractionation of olivine \pm pyroxene beneath the formation level of the gabbronorite cumulates. The cumulus mineral assemblage of the gabbros (Fo $\sim 80$ olivine $\pm \mathrm{An} \sim 70$ plagioclase + clinopyroxene + orthopyroxene + Ti-rich hornblende \pm oxide \pm apatite) represents up to $70 \mathrm{vol}$. \% of the total volume. This assemblage crystallized within high-K calc-alkaline and shoshonitic magma reservoirs at temperatures higher than $900^{\circ} \mathrm{C}$ and pressures of $\sim 300$ and $\sim 400 \mathrm{MPa}$, respectively. The initial assemblages and inferred parental magma composition of the feeder zone layered gabbronorite, pyroxene-hornblende gabbronorite and the mafic sill complex upper hornblendegabbro are very similar. With our current dataset, it is not possible to distinguish whether they crystallized in one 


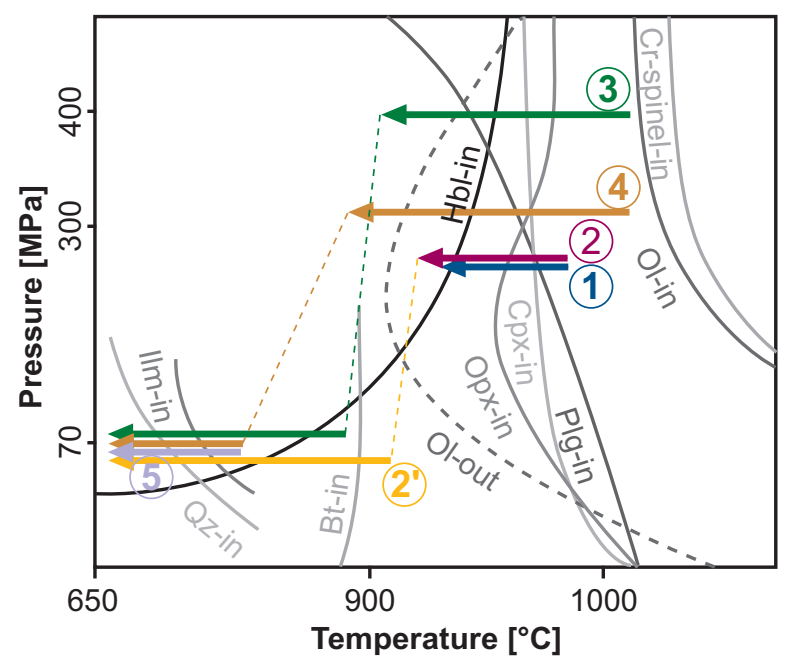

Fig. 19. Schematic $P-T$ phase diagram based on the experimental data of Ulmer (1988), Moore \& Carmichael (1998), Grove et al. (2003) and Rutherford \& Devine (2003). All mineral stability fields may vary as a function of pressure, temperature, liquid composition, water content and oxygen fugacity. The five trends show the evolution of the TPIC rock types, determined from the crystallization sequence (Fig. 6) and the calculated temperatures and pressures (1, layered gabbronorite; 2 pyroxene-hornblende gabbronorite; 2', Unit I granite; 3, lower hornblende-gabbro; 4 , upper hornblende-gabbro; 5 , feeder zone and mafic sill complex monzodiorites). Mineral abbreviations as in Fig. 4.

compositionally zoned and periodically refilled mid-crustal magma chamber, or in two or more small distinct reservoirs. Based on the $\mathrm{Sr}-\mathrm{Nd}-\mathrm{Pb}$ isotope compositions of the TPIC, Leuthold et al. (2013) proposed that country-rock assimilation principally occurred in this deep magma reservoir, prior to emplacement at the laccolith level. The occurrence of anhedral An 50 plagioclase cores overgrown by An 70 primocrysts suggests that the assimilated countryrock may have had a gabbroic-dioritic composition.

In contrast, lower and upper hornblende-gabbro matrix crystals (An $\sim 30$ plagioclase + Mg-rich hornblende + biotite + quartz + K-feldspar + apatite + titanite + oxide) have formed in situ, at a pressure of $\sim 70 \mathrm{MPa}$ and a temperature lower than $\sim 830^{\circ} \mathrm{C}$. Following the above discussion, concentrically cracked plagioclase and hornblende core textures are best explained by magma decompression during crystallization. The differences in the observed crystallization sequences between the TPIC gabbroic units are best explained by the diversity of parental magma compositions (with different $\mathrm{Na}_{2} \mathrm{O}, \mathrm{K}_{2} \mathrm{O}$ and $\mathrm{H}_{2} \mathrm{O}$ contents; Leuthold et al., 2013).

There are two possible processes responsible for magma ascent to the laccolith: (1) accumulated crystals on the floor, along the wall and also at the roof of a magma chamber (e.g. Tepley \& Davidson, 2003) might be disrupted and transported in a rising derivative low-density liquid; (2) a crystal mush at near-solidus conditions can be rejuvenated by partial melting, and remobilized by new magma injection (Murphy et al., 2000; Couch et al., 2001; Wiebe et al., 2004). Because there are very few transported crystal aggregates, but mostly single grains and their respective inclusions, we conclude that the deep reservoir was poorly consolidated. We speculate that a recharge (basaltic-) trachyandesite magma rejuvenated the crystal mush. This magma was over-pressured and started to rise (e.g. Rubin, 1995; Petcovic \& Dufek, 2005).

\section{GONGLUSIONS}

This study shows the importance of combining field relationships, mineral textures and mineral chemistry to obtain a better understanding of magma ascent and emplacement processes. The Torres del Paine intrusive complex in Patagonia is the ideal place to study magma movement in three dimensions, from the feeder zone to an associated sill complex.

We propose a geological model that links the growth and evolution of the sill complex, its feeding system and its root zone that encompasses a total duration of about 160 kyr (Leuthold et al., 2012), summarized in Fig. 20. We have distinguished shoshonitic and high-K calc-alkaline (Leuthold et al., 2013) magma reservoirs at $\sim 400$ and $\sim 300 \mathrm{MPa}$ and $>900^{\circ} \mathrm{C}$ and we have inferred olivine fractionation at a level below the upper crustal mush zone. Olivine + clinopyroxene + orthopyroxene + hornblende \pm An70 plagioclase \pm apatite were transported from the plutonic roots to the intrusive complex in stocks. Magma ascent was triggered by magma replenishment and resulting overpressure. Interstitial crystal-poor, high-silica rhyolite was efficiently expelled from the magma reservoir, and also during magma ascent shearing and during postemplacement compaction. The expelled magma crystallized as granite at depth of less than $3 \mathrm{~km}(70 \mathrm{MPa})$. Not only are the Unit I granite and the gabbronorite geochemically and spatially associated (Leuthold et al., 2013), but $\mathrm{U}-\mathrm{Pb}$ zircon geochronology suggests that they crystallized simultaneously (Leuthold et al., 2012). The olivine gabbronorite crystal mush thus traces the conduit and exhibits syn-magmatic shearing and strain partitioning, documented by a spectacular centimetre-scale vertically layered structure of felsic and mafic components. Successive mafic to silicic crystal mushes containing up to $\sim 40 \%$ crystals were emplaced subhorizontally in the Torres del Paine mafic sill complex, as a braided sill complex. Interstitial liquid was expelled from the crystal mush during and after sill emplacement. Minor postemplacement in situ differentiation is expressed by local accumulation of interstitial liquid leading to convective instabilities at the base of the overlying hornblendegabbro to monzodiorite sills.

The TPIC represents a unique opportunity to study a sill complex and its feeder zone in three dimensions. Our geological model provides an integrated analysis of the formation of bimodal intrusions by reconciling high-silica 

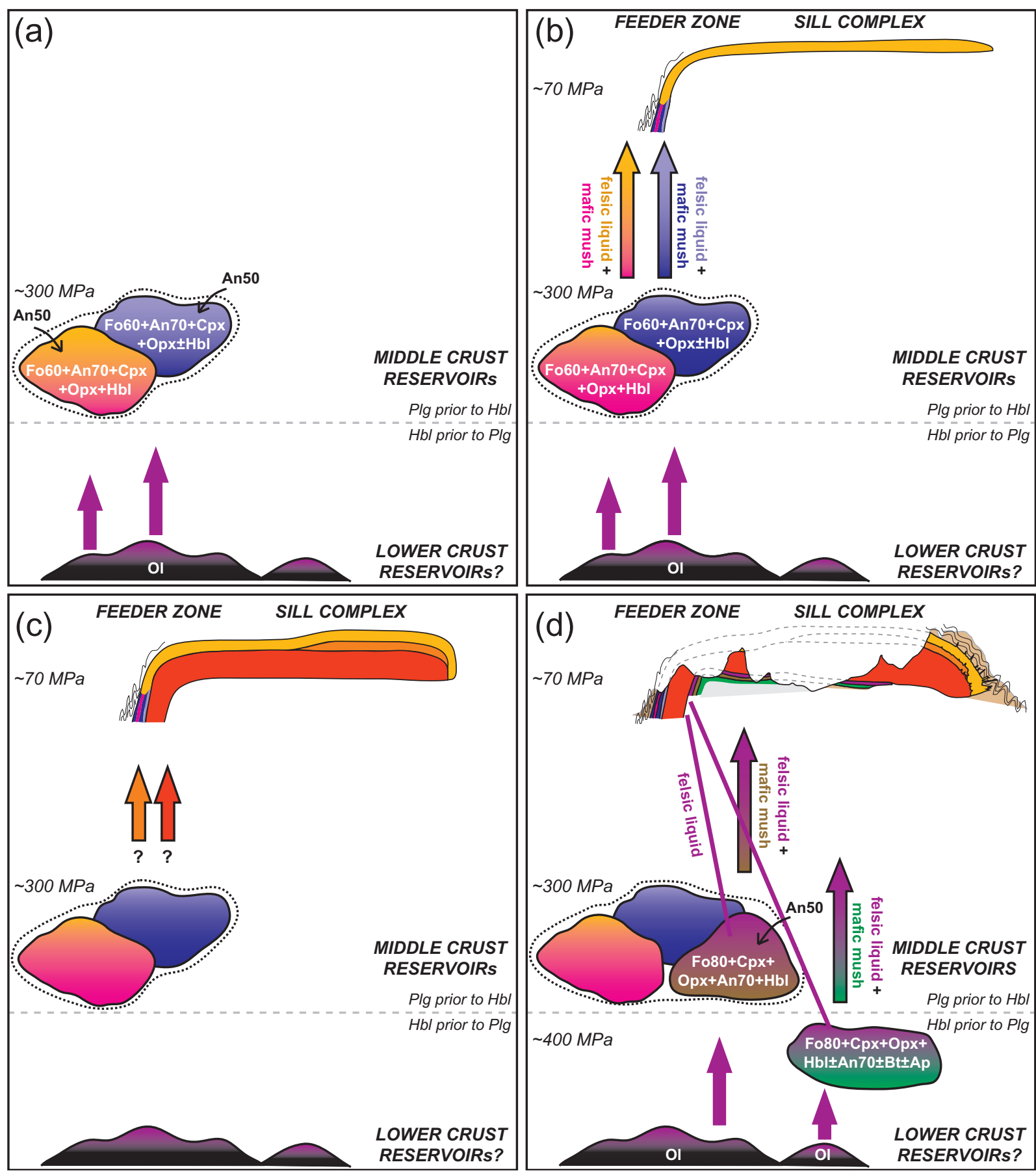

Fig. 20. Schematic illustration depicting the evolution of the magmatic plumbing system of the Torres del Paine intrusive complex. (a) Olivine fractionation in a deep crustal basaltic reservoir. The differentiated product is a high-K calc-alkaline basaltic trachyandesitic liquid. The high$\mathrm{K}$ calc-alkaline basaltic trachyandesitic magma ascends to mid-crustal depths, forming one or several magma reservoirs, at $\sim 300 \mathrm{MPa}$ and evolves by AFC processes to form the TPIC granites (at least Unit I) and gabbroic crystal mushes (gabbronorite and pyroxene-hornblende gabbronorite). (b) New magma infill rejuvenates the felsic liquid and percolates into the gabbroic crystal mush. The magma overpressure forces magma ascent to feed the sill system of the Torres del Paine at $\sim 70 \mathrm{MPa}$. The segregated hot $\left(\sim 950^{\circ} \mathrm{C}\right)$ felsic liquid (Unit I granite) ascends faster than the dense, viscous mafic crystal mush. (c) Younger granite sills are under-accreted over a period of 90 kyr (Michel et al., 2008). Their mafic source currently remains unknown. (d) High-K calc-alkaline and shoshonitic basaltic trachyandesite liquids ascend and form magma reservoirs at $\sim 300$ and $\sim 400 \mathrm{MPa}$ respectively, and evolve by AFG processes to form hornblende-gabbro crystal mushes. The middle crust crystal mushes are rejuvenated by basaltic trachyandesite magma injections, ascend and build up the mafic sill complex over $42 \mathrm{kyr}$ (Leuthold et al., 2012). The lower and upper hornblende-gabbros and the monzodiorite sills form a braided sill complex. Mineral abbreviations as in Fig. 4 . 
granites crystallized from a crystal-poor rhyolitic liquid with a mobilized olivine gabbronorite crystal mush. Once the plumbing system between an upper crustal magma reservoir at 9-12 km and the emplacement level is sufficiently stable, denser trachybasaltic magmas with up to $40 \%$ crystal cargo were underplated beneath the TPIC granite, forming a mafic sill complex.

\section{AGKNOWLEDGEMENTS}

We thank M. Jutzeler and A. Vandelli for assistance during fieldwork. We are grateful to Tom Sisson and Mikel Diez for constructive discussions. We thank the responsible authorities of CONAF (Corporacion Nacional Forestal, Chile) for granting permission to collect in the Torres del Paine National Park, and for their co-operation and hospitality. Scott Paterson, Kent Ratajeski and C. Miller are gratefully acknowledged for their constructive and encouraging reviews.

\section{F UN DI N G}

Fieldwork during the Paine Expeditions 2007 and 2008 was supported by funds from the Herbette Foundation and the Swiss Institute for Alpine Research to L.P.B. and O.M. We are grateful for Grants 200020-120120 and 20021105421 to L.P.B and Grants 200020-135511 and PDAMP2122074 to O.M from the Swiss National Science Foundation.

\section{SUPPLEMENTARY DATA}

Supplementary data for this paper are available at fournal of Petrology online.

\section{REFERENGES}

Aarnes, I., Podladchikov, Y. Y. \& Neumann, E.-R. (2008). Postemplacement melt flow induced by thermal stresses: Implications for differentiation in sills. Earth and Planetary Science Letters 276, 152-166.

Anderson, J. L. \& Smith, D. R. (1995). The effects of temperature and $f \mathrm{O}_{2}$ on the Al-in-hornblende barometer. American Mineralogist 80, 549-559.

Barclay, J. \& Carmichael, I. S. E. (2004). A hornblende basalt from western Mexico: water-saturated phase relations constrain a pressure-temperature window of eruptibility. Fournal of Petrology 45(3), 485-506

Baumgartner, L. P., Michel, J., Darbellay, B., Putlitz, B. \& Robyr, M. (2006). The geology of the Torres del Paine Laccolith, S Chile. Backbone of the Americas - Patagonia to Alaska. Geological Society of America: Abstracts with Programs, Speciality Meeting, Mendoza. Argentina: Paper no. 4-9.

Baumgartner, L. P., Michel, J., Putlitz, B., Leuthold, J., Müntener, O., Robyr, M. \& Darbellay, B. (2007). Field guide to the Torres del Paine Igneous Complex and its contact aureole. In: Demant, A., Hervé, F., Menichetti, M. \& Tassone, A. (eds) Field Guide Book GEOSUR 2007. Bolletino de Geofisica, GEOSUR 2007, International Congress on the Southern Hemisphere, Santiago de Chile, 185 p.
Bédard, J. H., Marsh, B. D., Hersum, T. G., Haslund, H. R. \& Mukasa, S. B. (2007). Large-scale mechanical redistribution of orthopyroxene and plagioclase in the Basement Sill, Ferrar Dolerites, McMurdo Dry Valleys, Antarctica: petrological, mineral-chemical and field evidence for channelized movement of crystals and melt. Fournal of Petrology 48(12), 2289-2326.

Bédard, J. H., Leclerc, F., Harris, L. B. \& Goulet, N. (2009). Intra-sill magmatic evolution in the Cummings Complex, Abitibi greenstone belt: Tholeiitic to calc-alkaline magmatism recorded in an Archean subvolcanic conduit system. Lithos 111, 47-71.

Berlo, K., Blundy, J., Turner, S. \& Hawkesworth, C. (2007). Textural and chemical variation in plagioclase phenocrysts from the 1980 eruptions of Mount St. Helens, USA. Contributions to Mineralogy and Petrology 154, 291-308.

Blundy, J. \& Cashman, K. (2001). Ascent-driven crystallization of dacite magmas at Mount St Helens, 1980-1986. Contributions to Mineralogy and Petrology 140, 631-650.

Blundy, J. \& Holland, T. J. B. (1990). Calcic amphibole equilibria and a new amphibole-plagioclase geothermometer. Contributions to Mineralogy and Petrology 104, 208-224.

Blundy, J. D. \& Shimizu, N. (1991). Trace element evidence for plagioclase recycling in calc-alkaline magmas. Earth and Planetary Science Letters 102, 178-197.

Bodner, R. (2013). Metamorphism and kinetics in the Torres del Paine contact aureole. PhD thesis, University of Lausanne, $164 \mathrm{p}$.

Boynton, W. V. (1984). Cosmochemistry of the rare earth elements: meteorite studies. In: Boynton, W. V. (ed.) Rare Earth Element Geochemistry. Elsevier, pp. 63-114.

Caricchi, L., Burlini, L., Ulmer, P., Gerya, T., Vassalli, M. \& Papale, P. (2007). Non-Newtonian rheology of crystal-bearing magmas and implications for magma ascent dynamics. Earth and Planetary Science Letters 264, 402-419.

Cashman, K. V. \& Blundy, J. (2000). Degassing and crystallization of ascending andesite and dacite. Philosophical Transactions of the Royal Society of London, Series A 358, 1487-1513.

Chiaradia, M., Müntener, O., Beate, B. \& Fontignie, D. (2009). Adakite-like volcanism of Ecuador: lower crust magmatic evolution and recycling. Contributions to Mineralogy and Petrology 158, 563-588.

Coleman, D. S., Gray, W. \& Glazner, A. F. (2004). Rethinking the emplacement and evolution of zoned plutons: Geochronologic evidence for incremental assembly of the Tuolumne Intrusive Suite, California. Geology 32(5), 433-436.

Costa, F., Chakraborty, S. \& Dohmen, R. (2003). Diffusion coupling between trace and major elements and a model for calculation of magma residence times using plagioclase. Geochimica et Cosmochimica Acta 67(12), 2189-2200.

Couch, S., Sparks, R. S. \& Carroll, M. R. (2001). Mineral disequilibrium in lavas explained by convective self-mixing in open magma chambers. Nature 411, 1037-1039.

Cruden, A. R. \& McCaffrey, K. J. W. (2002). Different scaling laws for sills, laccoliths and plutons: mechanical thresholds on roof lifting and floor depression. In: Breitkreuz, C., Mock, A. \& Petford, N. (eds) First International Workshop: Physical Geology of Subvolcanic Systems-Laccoliths, Sills, and Dykes (LASI). Wissenschaftliche Mitteilungen des Instituts für Geologie der TU Bergakademie Freiberg 20 , $15-17$.

Davidson, J., Tepley, F., Palacz, Z. \& Meffan-Main, S. (2001). Magma recharge, contamination and residence times revealed by in situ laser ablation isotopic analysis of feldspar in volcanic rocks. Earth and Planetary Science Letters 184, 427-442.

de Saint-Blanquat, M., Habert, G., Horsman, E., Morgan, S. S., Tikoff, B., Launeau, P. \& Gleizes, G. (2006). Mechanisms and duration of non-tectonically assisted magma emplacement in the 
upper crust: The Black Mesa pluton, Henry Mountains, Utah. Tectonophysics 428, $1-31$.

de Saint-Blanquat, M., Horsman, E., Habert, G., Morgan, S. S., Vanderhaeghe, O., Law, R. \& Tikoff, B. (2011). Multiscale magmatic cyclicity, duration of pluton construction, and the paradoxical relationship between tectonism and plutonism in continental arcs. Tectonophysics 500, 20-33.

Dingwell, D. B. (2006). Transport properties of magmas: Diffusion and rheology. Elements 2, 281-286.

Dungan, M. A. \& Davidson, J. (2004). Partial assimilative recycling of the mafic plutonic roots of arc volcanoes: An example from Chilean Andes. Geology 32(9), 773-776.

Galerne, C. Y., Neumann, E.-R. \& Planke, S. (2008). Emplacement mechanisms of sill complexes: Information from the geochemical architecture of the Golden Valley Sill Complex, South Africa. Fournal of Volcanology and Geothermal Research 177, 425-440.

Galerne, C. Y., Galland, O., Neumann, E.-R. \& Planke, S. (2011). 3D relationships between sills and their feeders: evidence from the Golden Valley Sill Complex (Karoo Basin) and experimental modelling. Fournal of Volcanology and Geothermal Research 202, 189-199.

Gibb, F. G. F. \& Henderson, C. M. B. (1992). Convection and crystal settling in sills. Contributions to Mineralogy and Petrology 109(4), 538-545.

Gibb, F. G. F. \& Henderson, C. M. B. (2006). Chemistry of the Shiant Isles main sill, NW Scotland, and wider implications for the petrogenesis of mafic sills. Fournal of Petrology 47(1), 191-230.

Ginibre, C., Wörner, G. \& Kronz, A. (2007). Crystal zoning as an archive for magma evolution. Elements 3, 261-266.

Glazner, A. F., Bartley, J. M., Coleman, D. S., Gray, W. \& Taylor, Z. (2004). Are plutons assembled over millions of years by amalgamation from small magma chambers? GSA Today 14(4-5), 4-11.

Grove, T. L. \& Donnelly-Nolan, J. M. (1986). The evolution of young silicic lavas at Medicine Lake Volcano, California: implications for the origin of compositional gaps in calc-alkaline series lavas. Contributions to Mineralogy and Petrology 92(3), 281-302.

Grove, T. L., Elkins-Tanton, L. T., Parman, S. W., Chaterjee, N., Müntener, O. \& Gaetani, G. A. (2003). Fractional crystallization and mantle-melting controls on calc-alkaline differentiation trends. Contributions to Mineralogy and Petrology 145, 515-533.

Gudmundsson, A. (2011). Deflection of dykes into sills at discontinuities and magma chamber formation. Tectonophysics $\mathbf{5 0 0 ( 1 - 4 ) , 5 0 - 6 4 . ~}$

Hansen, D. M., Cartwright, J. A. \& Thomas, D. (2004). 3D seismic analysis of the geometry of igneous sills and sill junction relationships. In: Davies, R. J., Cartwright, J. A., Stewart, S. A., Lappin, M. \& Underhill, J. R. (eds) 3D Seismic Technology: Application to the Exploration of Sedimentary Basins: Geological Society, London, Memoirs, pp. 199-208.

Holland, T. \& Blundy, J. (1994). Non-ideal interactions in calcic amphiboles and their bearing on amphibole- plagioclase thermometry. Contributions to Mineralogy and Petrology 104, 208-224.

Holness, M. B. \& Winpenny, B. (2009). The Unit 12 allivalite, Eastern Layered Intrusion, Isle of Rum: a textural and geochemical study of an open-system magma chamber. Geological Magazine 146(3), 437-450.

Holness, M. B., Hallworth, M. A., Woods, A. \& Sides, R. E. (2007). Infiltration metasomatism of cumulates by intrusive magma replenishment: the Wavy Horizon, Isle of Rum, Scotland. Fournal of Petrology 48(3), 563-587.

Holtzman, B. K., Kohlstedt, D. L. \& Phipps Morgan, J. (2005). Viscous energy dissipation and strain partitioning in partially molten rocks. Fournal of Petrology 46(12), 2569-2592.

Horsman, E., Morgan, S., de Saint-Blanquat, M., Habert, G., Nugent, A., Hunter, R. A. \& Tikoff, B. (2010). Emplacement and assembly of shallow intrusions from multiple magma pulses, Henry Mountains, Utah. Earth and Environmental Science Transactions of the Royal Society of Edinburgh 100, 117-132.

Hoshide, T. \& Obata, M. (2010). Zoning and resorption of plagioclase in a layered gabbro, as a petrographic indicator of magmatic differentiation. Earth and Environmental Science Transactions of the Royal Society of Edinburgh 100, 235-249.

Irvine, T. N. (1980). Magmatic infiltration metasomatism, doublediffusive fractional crystallization, and adcumulus growth in the Muskox intrusion and other layered intrusions. In: Hargraves, R. B. (ed.) Physics of Magmatic Processes. Princeton University Press, pp. $325-383$.

Jackson, M. D. \& Pollard, D. D. (1988). The laccolith-stock controversy: New results from the southern Henry Mountains, Utah. Geological Society of America Bulletin 100(1), 117-139.

Jackson, S. E. (2008). LAMTRACE data reduction software for LAICP-MS. In: Sylvester, P. (ed.) Laser Ablation ICP-MS in the Earth Sciences: Current Practices and Outstanding Issues. Mineralogical Association of Canada, Short Course Series 40, 305-307.

Johnson, A. M. \& Pollard, D. D. (1973). Mechanics of growth of some laccolithic intrusions in the Henry Mountains, Utah, I. Tectonophysics 18, 261-309.

Kavanagh, J. L., Menand, T. \& Sparks, R. S. J. (2006). An experimental investigation of sill formation and propagation in layered elastic media. Earth and Planetary Science Letters 245, 799-813.

Kuritani, T. (1998). Boundary layer crystallization in a basaltic magma chamber: evidence from Rishiri Volcano, northern Japan. Fournal of Petrology 39(9), 1619-1640.

Latypov, R. M. (2003). The origin of basic-ultrabasic sills with S-, Dand I-shaped compositional profiles by in situ crystallization of a single input of phenocryst-poor parental magma. Fournal of Petrology 44(9), 1619-1656.

Lavallée, Y., Mitchell, T. M., Heap, M. J., Vasseur, J., Hess, K.-U., Hirose, T. \& Dingwell, D. B. (2012). Experimental generation of volcanic pseudotachylytes: Constraining rheology. Fournal of Structural Geology 38, 222-233.

Leuthold, J., Muntener, O., Baumgartner, L. P., Putlitz, B., Ovtcharova, M. \& Schaltegger, U. (2012). Time resolved construction of a bimodal laccolith (Torres del Paine, Patagonia). Earth and Planetary Science Letters 325-326, 85-92.

Leuthold, J., Muntener, O., Baumgartner, L. P., Putlitz, B. \& Chiaradia, M. (2013). A detailed geochemical study of a shallow, arc-related laccolith: the Torres del Paine mafic complex, Patagonia. Fournal of Petrology 54(2), 273-303.

Lindsley, D. H. (1983). Pyroxene thermometry. American Mineralogist 68, $477-493$.

Mader, H. M., Llewellin, E. W. \& Mueller, S. P. (2013). The rheology of two phase magmas: A review and analysis. Fournal of Volcanology and Geothermal Research 257, 135-158.

Marsh, B. D. (1981). On the crystallinity, probability of occurrence, and rheology of lava and magma. Contributions to Mineralogy and Petrology 78, 85-98.

Mattinson, J. M. (2005). Zircon U-Pb chemical abrasion ('CATIMS') method: Combined annealing and multi-step partial dissolution analysis for improved precision and accuracy of zircon ages. Chemical Geology 220, 47-66.

Mattioli, M., Serri, G., Salvioli-Mariani, E., Renzulli, A., Holm, P. M., Santi, P. \& Venturelli, G. (2003). Sub-volcanic infiltration and syn-eruptive quenching of liquids in cumulate wall-rocks: the example of the gabbroic nodules of Stromboli (Aeolian Islands, Italy). Mineralogy and Petrology 78, 201-230.

Menand, T. (2008). The mechanics and dynamics of sills in layered elastic rocks and their implications for the growth of laccoliths 
and other igneous complexes. Earth and Planetary Science Letters 267, 93-99.

Menand, T. (2011). Physical controls and depth of emplacement of igneous bodies: A review. Tectonophysics 500(1-4), 11-19.

Meurer, W. P. \& Boudreau, A. E. (1998). Compaction of igneous cumulates. Part I-Geochemical consequences for cumulates and liquid fractionation trends. Fournal of Geology 106, 293-304.

Michael, P. J. (1991). Intrusion of basaltic magma into a crystallizing granitic magma chamber: the Cordillera del Paine pluton in southern Chile. Contributions to Mineralogy and Petrology 108(4), 396-418.

Michel, J., Baumgartner, L., de Saint-Blanquat, M., Putlitz, B., Sanchez, A., Darbellay, B. \& Cavargna, M. (2007). Magnetic fabric of the Torres del Paine, Patagonia. American Geophysical Union, Fall Meeting, San Francisco, USA, Abstract \#V33C-1524.

Michel, J., Baumgartner, L., Putlitz, B., Schaltegger, U. \& Ovtcharova, M. (2008). Incremental growth of the Patagonian Torres del Paine laccolith over 90 ky. Geology 36(6), 459-465.

Miller, C. F., Furbish, D. J., Walker, B. A., Claiborne, L. L., Koteas, G. C., Bleick, H. A. \& Miller, J. S. (2011). Growth of plutons by incremental emplacement of sheets in crystal-rich host: Evidence from Miocene intrusions of the Colorado River region, Nevada, USA. Tectonophysics 500(1-4), 65-77.

Miller, J. S., Matzel, J. E. P., Miller, C. F., Burgess, S. D. \& Miller, R. B. (2007). Zircon growth and recycling during the assembly of large, composite arc plutons. Fournal of Volcanology and Geothermal Research 167, 282-299.

Molina, J. F., Scarrow, J. H., Montero, P. G. \& Bea, F. (2009). High-Ti amphibole as a petrogenetic indicator of magma chemistry: evidence for mildly alkalic-hybrid melts during evolution of Variscan basic-ultrabasic magmatism of Central Iberia. Contributions to Mineralogy and Petrology 158(1), 69-98.

Moore, G. \& Carmichael, I. S. E. (1998). The hydrous phase equilibria (to $3 \mathrm{kbar}$ ) of an andesite and basaltic andesite from western Mexico: constraints on water content and conditions of phenocryst growth. Contributions to Mineralogy and Petrology 130, 304-319.

Murphy, M. D., Sparks, R. S. J., Barclay, J., Carolle, M. R. \& Brewer, T. S. (2000). Remobilization of andesite magma by intrusion of mafic magma at the Soufrière Hills Volcano, Montserrat, West Indies. Fournal of Petrology 41(1), 21-42.

Nakagawa, M., Wada, K. \& Wood, C. P. (2002). Mixed magmas, mush chambers and eruption triggers: evidence from zoned clinopyroxene phenocrysts in andesitic scoria from the 1995 eruptions of Ruapehu Volcano, New Zealand. Fournal of Petrology 43, 2279-2303.

Paterson, S. R., Zák, J. \& Janousek, V. (2008). Growth of complex sheeted zones during recycling of older magmatic units into younger: Sawmill Canyon area, Tuolumne batholith, Sierra Nevada, California. Fournal of Volcanology and Geothermal Research 177, 457-484.

Petcovic, H. L. \& Dufek, J. D. (2005). Modeling magma flow and cooling in dikes: Implications for the emplacement of Columbia River flood basalts. Fournal of Geophysical Research 110, B10201.

Pistone, M., Caricchi, L., Ulmer, P., Burlini, L., Ardia, P., Reusser, E., Marone, F. \& Arbaret, L. (2012). Deformation experiments of bubble- and crystal-bearing magmas: Rheological and microstructural analysis. Fournal of Geophysical Research 117, B05208.

Pistone, M., Caricchi, L., Ulmer, P., Reusser, E. \& Ardia, P. (2013). Rheology of volatile-bearing crystal mushes: mobilization vs. viscous death. Chemical Geology 345, 16-39.

Pollard, D. D. \& Johnson, A. M. (1973). Mechanics of growth of some laccolithic intrusions in the Henry Mountains, Utah, II. Tectonophysics 18, 311-354.

Pollard, D. D., Muller, O. H. \& Dockstader, D. R. (1975). The form and growth of fingered sheet intrusions. Geological Society of America Bulletin 3, 351-363.
Polteau, S., Mazzini, A., Galland, O., Planke, S. \& Malthe-Sorenssen, A. (2008). Saucer-shaped intrusions: Occurrences, emplacement and implications. Earth and Planetary Science Letters 266, 195-204.

Putlitz, B., Baumgartner, L. P., Oberhaensli, R., Diamond, L. \& Altenberger, U. (2001). The Torres del Paine Laccolith (Chile); intrusion and metamorphism. XI Annual V. M. Goldschmidt Proceedings, Virginia, USA, Abstract \#3534.

Reubi, O. \& Blundy, J. (2008). Assimilation of plutonic roots, formation of high-K 'exotic' melt inclusions and genesis of andesitic magmas at Volcan de Colima, Mexico. Fournal of Petrology 49(12), 2221-2243.

Ridolfi, F. \& Renzulli, A. (2012). Calcic amphiboles in calc-alkaline and alkaline magmas: thermobarometric and chemometric empirical equations valid up to $1,130^{\circ} \mathrm{C}$ and $2 \cdot 2 \mathrm{GPa}$. Contributions to Mineralogy and Petrology 163(5), 877-895.

Roman-Berdiel, T., Gapais, D. \& Brun, J. P. (1995). Analogue models of laccolith formation. Fournal of Structural Geology 17(9), 1337-1346.

Rubin, A. M. (1995). Getting granite dikes out of the source region. Journal of Geophysical Research 100(B4), 5911-5929.

Rutherford, M. J. \& Devine, J. D. (2003). Magmatic conditions and magma ascent as indicated by hornblende phase equilibria and reactions in the 1995-2002 Soufrière Hills magma. Fournal of Petrology 44(8), 1433-1454.

Sisson, T. W. \& Grove, T. L. (1993). Experimental investigations of the role of $\mathrm{H}_{2} \mathrm{O}$ in calc-alkaline differentiation and subduction zone magmatism. Contributions to Mineralogy and Petrology 113, 143-166.

Sisson, T. W., Grove, T. L. \& Coleman, D. S. (1996). Hornblende gabbro sill complex at Onion Valley, California, and a mixing origin for the Sierra Nevada batholith. Contributions to Mineralogy and Petrology 126, 81-108.

Sisson, T. W., Ratajeski, K., Hankins, W. B. \& Glazner, A. F. (2005). Voluminous granitic magmas from common basaltic sources. Contributions to Mineralogy and Petrology 148, 635-661.

Sobolev, A. V., Hofmann, A. W., Kuzmin, D. V., Yaxley, G. M., Arndt, N. T., Chung, S.-L., Danyushevsky, L. V., Elliott, T., Frey, F. A., Garcia, M. O., Gurenko, A. A., Kamenetsky, V. S., Kerr, A. C., Krivolutskaya, N. A., Matvienkov, V. V., Nikogosian, I. K., Rocholl, A., Sigurdsson, I. A., Sushchevskaya, N. M. \& Teklay, M. (2007). The amount of recycled crust in sources of mantle-derived melts. Science 316, 412-417.

Streck, M. J. (2008). Mineral textures and zoning as evidence for open system processes. In: Putirka, K. D. \& Tepley, F. J., III (eds) Minerals, Inclusions and Volcanic Processes. Mineralogical Society of America and Geochemical Society, Reviewes in Mineralogy and Geochemistry 69, 595-622.

Tepley, J. F. \& Davidson, J. P. (2003). Mineral-scale Sr-isotope constraints on magma evolution and chamber dynamics in the Rum layered intrusion, Scotland. Contributions to Mineralogy and Petrology 145, 628-641.

Thomson, K. \& Hutton, D. (2004). Geometry and growth of sill complexes: insights using 3D seismic from the North Rockfall Trough. Bulletin of Volcanology 66, 364-375.

Ulmer, P. (1988). High pressure phase equilibria of calc-alkaline picrobasalt: implications for the genesis of calc-alkaline magmas. Carnegie Institution of Washington Yearbook, Annual Report of the Director of the Geophysical Laboratory 88, 28-34.

Vigneresse, J.-L., Barbey, P. \& Cuney, M. (1996). Rheological transitions during partial melting and crystallization with application to felsic magma segregation and transfer. Fournal of Petrology 37(6), 1579-1600.

Wallace, G. S. \& Bergantz, G. W. (2002). Wavelet-based correlation (WBG) of zoned crystal populations and magma mixing. Earth and Planetary Science Letters 202, 133-145. 
Wells, P. R. A. (1977). Pyroxene thermometry in simple and complex systems. Contributions to Mineralogy and Petrology 62, 129-139.

Wiebe, R. A. (1993). The Pleasant Bay layered gabbro-diorite, Coastal Maine: Ponding and crystallization of basaltic injections into a silicic magma chamber. Fournal of Petrology 34(3), 461-489.

Wiebe, R. A. \& Collins, W. J. (1998). Depositional features and stratigraphic sections in granitic plutons: implications for the emplacement and crystallization of granitic magma. Fournal of Structural Geology 20(9-10), 1273-1289.

Wiebe, R. A., Manon, M. R., Hawkins, D. P. \& McDonough, W. F. (2004). Late-stage mafic injection and thermal rejuvenation of the Vinalhaven Granite, coastal Maine. Fournal of Petrology 45(11), 2133-2153.

Wilson, T. J. (1983). Stratigraphic and structural evolution of the Ultima Esperanza foreland fold-thrust belt, Patagonian Andes, southern Chile. PhD thesis, Columbia University, New York, 360 p. 
